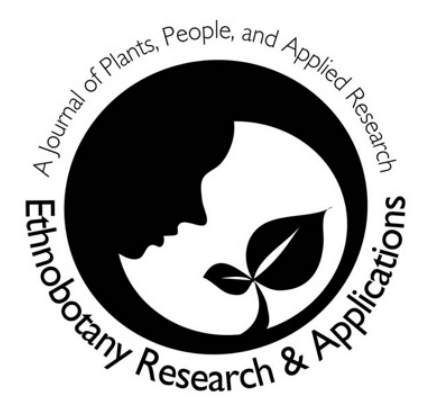

\title{
Ethnobotanical knowledge and threat factors for Aloe species in Tanzania
}

\author{
Siri A. Abihudi, Hugo J. de Boer, Rogasian L.A. \\ Mahunnah, Anna C. Treydte
}

\section{Research}

\begin{abstract}
Background: The genus Aloe has long been known for its use in healthcare and cosmetics. In Tanzania, overexploitation is threatening some Aloe species with extinction and yet, little has been documented on the abundance and biocultural uses.
\end{abstract}

Material and Methods: Semi-structured questionnaires were used to obtain ethnobotanical information from 236 respondents across 22 villages in four regions of Tanzania (Kilimanjaro, Tanga, Mara, Katavi-Rukwa).

Results: A total of 23 Aloe species were identified, 20 of which were being used locally and were mostly being collected from the wild. We report the uses of A. mzimbana, $A$. volkensii subsp. volkensii, $A$. leptosiphon, $A$. parvidens and $A$. bicomitum for the first time in East Africa. The most preferred species were $A$. lateritia, $A$. duckeri and $A$. secundiflora which are three common, widely distributed species. Diseases frequently treated with Aloe species include malaria and general stomachache in humans, and Newcastle disease in chickens. Some Aloe species were found to have gone extinct locally due to over-harvesting. Rare Aloe species were perceived to be less preferred as they mostly occurred far away from settlements.

Conclusions: We conclude that the genus Aloe is widely used across Tanzania and needs strong conservation measures to prevent individual species from becoming extinct in the wild.

Keywords: Distribution; Ethnobotany; Folk taxonomy; Perception; Sustainable harvesting.

\author{
Correspondence \\ Siri A. Abihudi ${ }^{1,3^{*}}$, Hugo J. de Boer ${ }^{2}$, Rogasian L. \\ A. Mahunnah ${ }^{3}$, Anna C. Treydte ${ }^{1,4}$ \\ ${ }^{1}$ Biodiversity Conservation and Ecosystem \\ Management, Nelson Mandela African Institution for \\ Science and Technology (NM-AIST), P.O. Box 447, \\ Arusha, Tanzania. \\ ${ }^{2}$ Natural History Museum, University of Oslo, P.O. \\ Box 1172, NO-0318 Oslo, Norway. \\ ${ }^{3}$ Department of Agronomy, Medical Botany and Plant \\ Breeding, Institute of Traditional Medicine, Muhimbili \\ University of Health and Allied Sciences, 65001, Dar \\ es Salaam, Tanzania. \\ ${ }^{4}$ Agroecology in the Tropics and Subtropics, Hans- \\ Ruthenberg Institute, University of Hohenheim, \\ 70593 Stuttgart, Germany. \\ *Correspondence: abihudis@nm-aist.ac.tz \\ Ethnobotany Research \& Applications \\ 18:43 (2019)
}

\section{Background}

Aloe species are common in tropical and subtropical areas of Africa (Carter 1994; Reynolds 2004; Wabuyele et al. 2006) and are found in a wide range of habitats, from forests to rock surfaces and cliffs (Reynolds 2004). They range in size from about 30 $\mathrm{cm}$ in height, e.g., Aloe brevifolia Mill. (Cousins \& Witkowski 2012) to $9 \mathrm{~m}$ for Aloe dichotoma (Reynolds 2004; Foden et al. 2007; Taylor et al. 2010; Warren et al. 2010). Aloe species were first documented in the Ebers Papyrus (1500 BC) and have been used both for physical and spiritual purposes (Aboelsoud 2010; Bennett and Brown 2000; Tomov 2018). Currently, Aloe vera Burm.f. is popularly used in traditional and pharmaceutical medicine due to its potential anti-inflammatory, antiarthritic, antibacterial and hypoglycaemic effects (Manvitha \& Bidya 2014; Pandey \& Mishra 2010; 
Shahzad \& Ahmed 2013; Yebpella et al. 2011). Other Aloe species might also be useful, but little has been done to promote their use or development for commercial purposes (Veríssimo 2016). For example, only three of South African Aloe species have been partially or fully commercialized (Van Wyk 2011).

Although there are therapeutic benefits of several Aloe species, infusions of some Aloe species such as $A$. chabaudii Schönland, $A$. christianii Reynolds and $A$. globuligemma Pole-Evans can also be deadly when taken in higher doses than recommended (Reynolds 2004). This lethal effect is due to alkaloids, which vary in content and concentration from species to species (Reynolds 2005). Aloe species have not only been used to treat burns, bruises and skin irritations but also for making traditional beer and herbal wine (Bjorå et al. 2015; Trivedi et al. 2012) and as fodder for livestock (Bjorå et al. 2015). Since some species are beneficial to humans while others might be lethal, there is an urgent need to properly identify Aloe species and their specific uses (Reynolds 2004).

Tanzania, a country rich in Aloe diversity, has approximately 46 Aloe species, 25 of which are endemic to the Tanzanian mainland (Reynolds 2004; Wabuyele \& Kyalo 2008). Some species are quite common but $31 \%$ are threatened, while the current population trend of some species is unknown (Wabuyele et al. 2008). For instance, among the five most critically endangered Tanzanian Aloe species, A. boscawenii Christian has not been seen or collected since the year 1953 (EAM \& CFCPAP 2009). The wide use of Aloe species by local people in Tanzania results from the traditional ways of treatment (Pili 2007) and has been documented across Tanzania such as in Mbozi, Kigoma and Morogoro Districts (Amir et al. 2019). However, little is known from other parts of the country on the use and the bio-cultural value of Aloe species. Therefore, there is an urgent need to understand not only the current distribution and use but also to predict the future accessibility of Tanzanian Aloe species, which could lead to conservation concerns in the protection of more species.

In this study, we assessed the folk taxonomy as well as indigenous knowledge of traditional use, growth and conservation of Aloe species. This study complements a previously published pilot study on Tanzanian Aloe ethnobotany (Amir et al. 2019).

\section{Materials and methods}

\section{Study area}

Ethnobotanical data were collected from December 2017 to August 2018 in Kilimanjaro, Tanga, Mara (Serengeti district) and Katavi-Rukwa regions of Tanzania (Table 1). The selected areas, except Serengeti district, are among the Tanzanian Aloe "hotspots" (Carter 1994). Serengeti district was added because it had never been surveyed before.

\section{Sampling technique}

Ethnobotanical data were collected based on the standards for collecting and reporting ethnopharmacological studies (Weckerle et al. 2018). Permission to conduct this study was obtained from respective district authorities. To study the distribution of Aloe species, a total of 18 out of 23 districts in the selected regions were visited and from each district, four to eight wards were surveyed. Ethnobotanical knowledge was collected from 22 villages in areas of known high Aloe species diversity (Fig. 1).

Respondents for this study were selected randomly to capture a wide range of ethnicities, ages, gender, and occupations (teachers, villagers, village leaders and traditional healers). A total of 236 respondents were interviewed, 91 in Tanga, 22 in Mara (Serengeti District), 56 in Kilimanjaro and 67 in Katavi-Rukwa regions. The youngest and oldest respondents were 18 and 85 years old, respectively (Fig. 2). The education level of most respondents was primary education $(70 \%)$, followed by lower secondary education (Ordinary Level) (14\%) and then no formal education (13\%). Most respondents had lived in the respective area for 10-30 years. Respondents spoke different local languages based on their tribe: Pare, Chaga, Kurya, Fipa, Sambaa, Bena, Muarusha, Lungu, Gongwe, Pimbwe, Sukuma, Nyiha, Kamba, Zigua, Digo, Maasai and Meru. Prior to interviews, informed consent was sought from the participants. A semi-structured questionnaire was administered to gather ethnobotanical knowledge from local respondents. We asked questions about the folk taxonomy of different Aloe species, their phenology, flowering season, estimated access to the species, possible threat factors, harvesting methods and timing, plant parts utilized, preparation, use and potential side effects. We supplemented questionnaires by participatory field visits with the villagers. During field visits, photos and direct field observations were used to confirm folk taxonomy for all the available species in the wild. We also collected voucher specimens from each site. Voucher specimens were deposited at the National 
Herbarium of Tanzania (NHT), Tropical Pesticides Research Institute (TPRI), Arusha, at the Institute of Traditional Medicine herbarium (ITM)- Muhimbili University of Health and Allied Sciences (MUHAS), and at the herbarium of the University of Dar-Es-
Salaam (DSM). Morphological identification of Aloe species followed Carter (1994). We consulted a botanist at the NHT, Botanist. Mr. Emmanuel Mboya, in case identification was difficult.

Table 1. Elevation, average annual rainfall, average annual temperature and habitat types covered in this research in the search for Aloe assessment in Tanzania.

\begin{tabular}{|c|c|c|c|}
\hline Region and habitat covered & Elevation (masl) & Rainfall (mm) & $\operatorname{Temp}\left({ }^{\circ} \mathrm{C}\right)$ \\
\hline \multicolumn{4}{|l|}{ Tanga } \\
\hline Dry plains (Handeni, Kilindi) & $200-600$ & $500-800$ & 22 \\
\hline $\begin{array}{l}\text { Mountain belt (Lushoto, Handeni, Kilindi) } \\
\text { Coastal belt (Mkinga, Pangani and Tanga } \\
\text { municipal) }\end{array}$ & $\begin{array}{c}1000-2000 \\
0-15\end{array}$ & $\begin{array}{l}800-2000 \\
800-1400\end{array}$ & $\begin{array}{l}17 \\
26\end{array}$ \\
\hline \multicolumn{4}{|l|}{ Kilimanjaro } \\
\hline $\begin{array}{l}\text { Highlands (Same, Rombo, Marangu) } \\
\text { Intermediate lands (Rombo, Same, Moshi } \\
\text { Rural district and Mwanga) } \\
\text { Lowlands (Mwanga, Same, Hai, Siha and } \\
\text { Moshi Rural district) }\end{array}$ & $\begin{array}{l}1000-1800 \\
900-1100 \\
900\end{array}$ & $\begin{array}{l}1250-2000 \\
800-1250 \\
700-900\end{array}$ & $\begin{array}{l}15-20 \\
20-30 \\
30+\end{array}$ \\
\hline Katavi and Rukwa & $1400-3400$ & $800-1300$ & $13-27$ \\
\hline Mara (Serengeti district) & $1300-1500$ & $900-1250$ & 28.5 \\
\hline
\end{tabular}
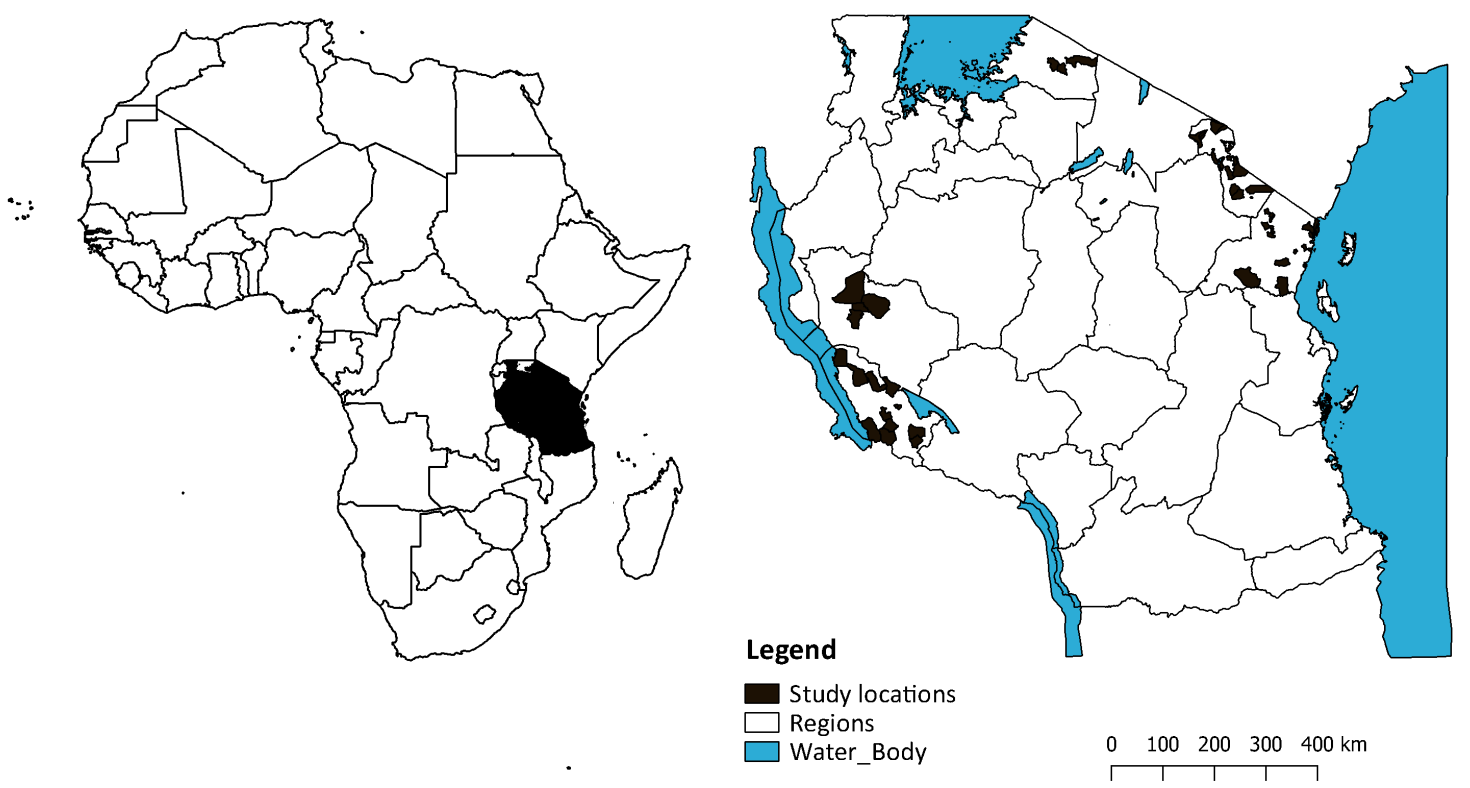

Figure 1. Map of Africa and Tanzania, with shaded areas showing where interviews ( $\mathrm{n}=18$ districts) were conducted on Aloe species distribution and use. 


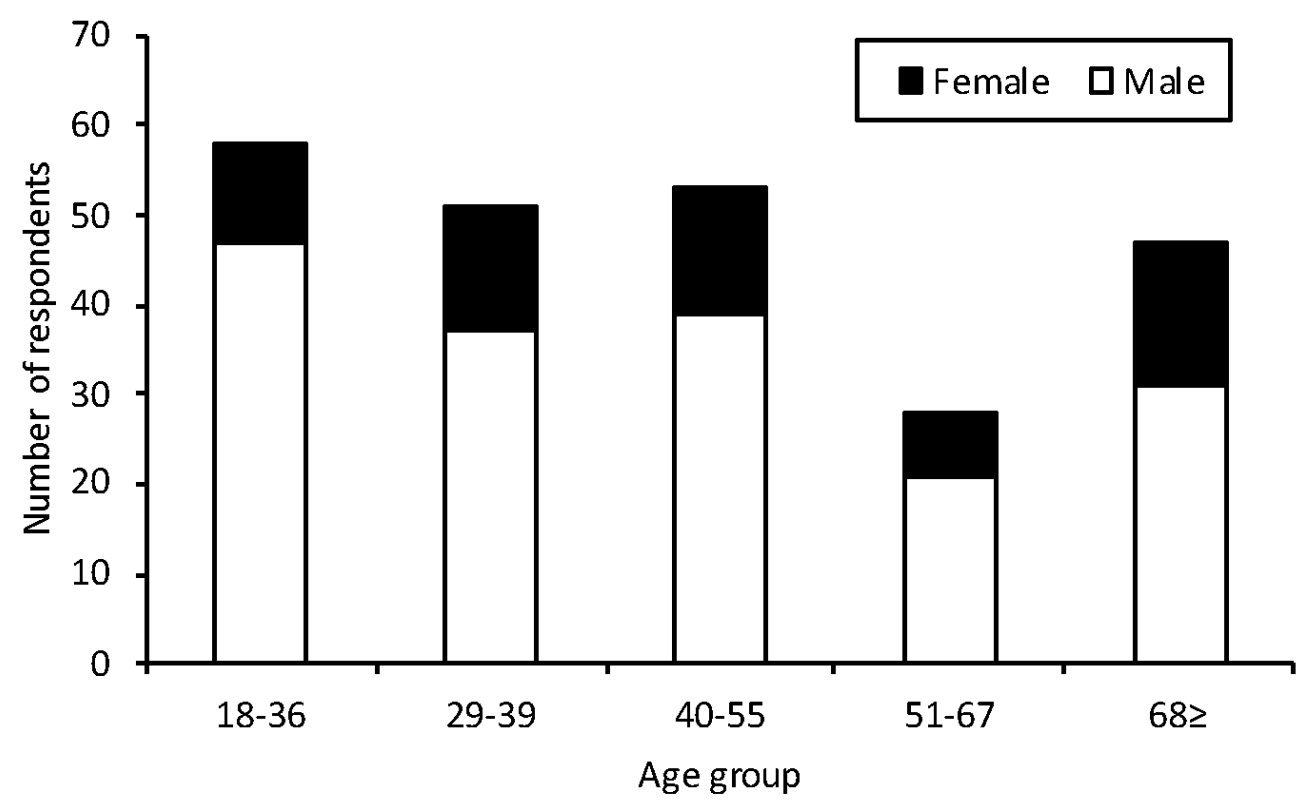

Figure 2. Age and gender distribution of all respondents $(n=236)$ across the four study regions within Tanzania that were asked about Aloe species distribution and their use.

\section{Data Analysis}

Data were analyzed using SPSS v. 20 (Sarper et al. 2009). Data were first tested for normality and equality of variance with Shapiro-Wilk and Kolmogorov-Smirnov tests at $\alpha=0.05$ (Srithi et al. 2009). Ethnobotanical knowledge (number of uses of Aloe species named by each respondent) and the relationship between age groups, gender, ethnobotanical knowledge and whether the perception of the possible disappearance of Aloe species was age-dependent werte analyzed using Msnn-Whitney U-tests. The link between perception on factors affecting Aloe species abundance and the number of Aloe species used was tested using the Kruskal Wallis Test (Number of uses = ethnobotanical knowledge). Correlation analysis was performed to determine if the number of uses was influenced by Aloe species richness and human population in a region.

\section{Results}

Folk taxonomy and flowering times of Aloe species

All respondents knew the Aloe species present in their area, and this was corroborated during our participatory field assessment. An overwhelming number of respondents $(93 \%, \mathrm{n}=221)$ mentioned that Aloe vera was the common name for all Aloe species in their area but then distinguished them by giving each a folk name in their local language (Supplementary Data Table S1). Most respondents distinguished Aloe species based on morphological characteristics. For example, the Pare people in
Kilimanjaro region called all Aloe species Kithapa but differentiated between the short and tall species, i.e., "Kithapa kidori" and "Kithapa kibaha", respectively. In addition, they differentiated some species based on their use, i.e., "Kithapa cha vujawa" (Aloe species for beer brewing). A local beer called "vujawa" is prepared from sugarcane and Aloe stems "miatini". The Aloe stems are added to give the beer an agreeable bitterness. A total of 151 (64\%) respondents were able to distinguish different Aloe species. Species were differentiated based on types of leaf spots $(62 \%)$, shoot height $(50 \%)$, leaf size $(19 \%)$, leaf colour $(10 \%)$, the taste of the sap $(3 \%)$, and habitat in which they were found $(3 \%)$. The remaining 86 respondents $(36 \%)$ claimed to have only one Aloe species in their area, but we often found more than one species during our field surveys. Most of the morphologically similar species were considered to be the same species by the respondents and were used for similar purposes, e.g., the "tall Aloes" $A$, ballyi Reynolds and $A$. volkensii Engl. and the "short Aloes" A. rabaiensis Rendle and $A$. deserti A. Berger.

The flowering periods of Aloe species followed the rainy season but differed based on the region and type of species (Fig. 3). In Kilimanjaro, Tanga and Katavi-Rukwa regions, most species flowered in June to August while in Mara (Serengeti District), most flowered from March to May. However, some species in the Tanga region, e.g., $A$. boscawenii, $A$. leptosiphon A. Berger and A. massawana Reynolds, flowered from January to March. 


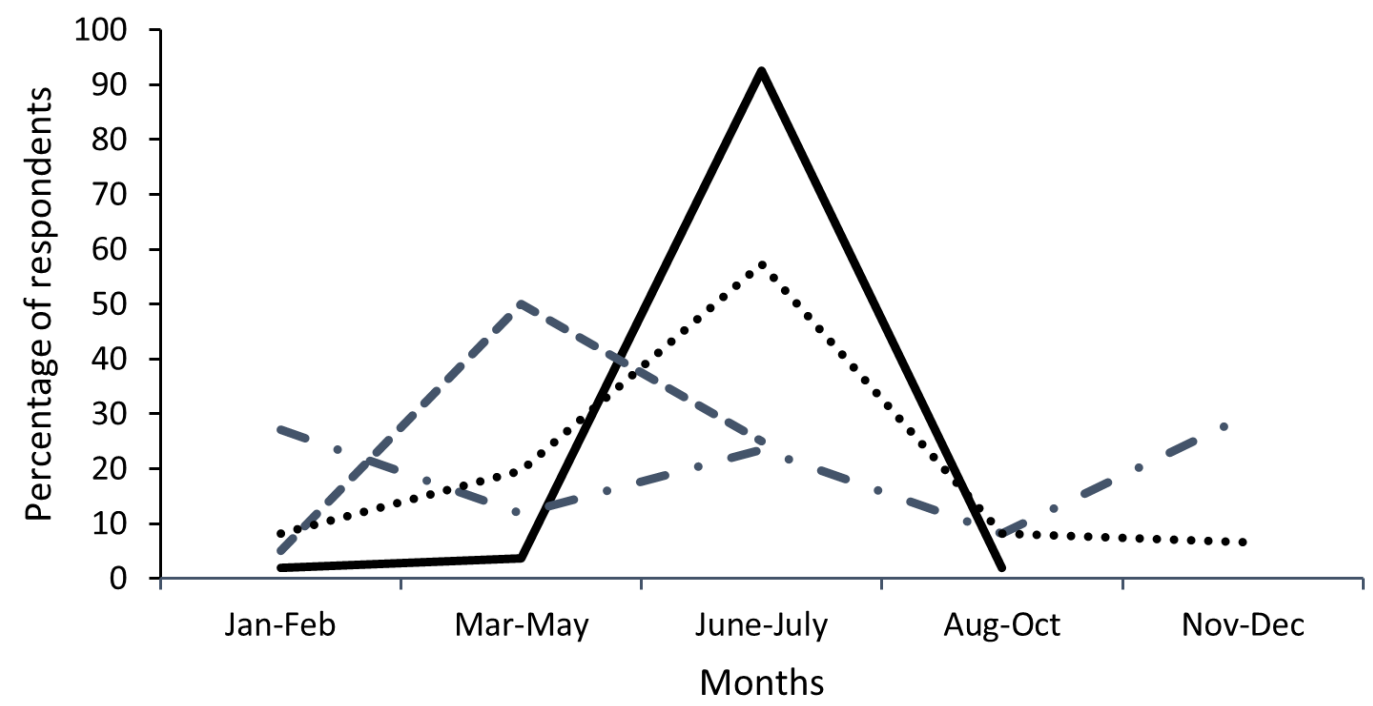

Kilimanjaro - - Serengeti - - Tanga ..... Former Rukwa

Figure 3. Aloe species flowering times reported by the study respondents (in $\%, n=236$ ) across the four study regions within Tanzania.

\section{Aloe species uses by local communities}

The level of ethnobotanical knowledge (number of different uses known for Aloe species) was significantly higher among older respondents (42-85 years) compared to younger respondents (18 to 41 years; $Z=2.144, p=0.032$ ). However, there was no difference in ethnobotanical knowledge between women and men $(Z=0.712, p=0.476)$. Respondents reported that mostly male family members, i.e., fathers (40\%) and grandfathers (29\%), passed on ethnobotanical knowledge, e.g., where to find and how to use Aloe species. Mothers also passed on ethnobotanical knowledge, although this occurred less frequently (13\%). Harvesting took place throughout the year but was mostly conducted during seasonal outbreaks of malaria in humans and Newcastle disease in chickens (i.e., following the rainy season). However, the harvest of Aloe species was reported to take place only when the need arises i.e. seasonal outbreak of diseases $(82 \%)$.

Twenty out of 23 Aloe species in the regions were mentioned to be useful (Fig. 4). There was a significant positive relationship between regions with a high human population and the number of uses of Aloe species ( $r=0.96, p=0.037$ ); however, there was no significant correlation between the diversity of Aloe species with the number of uses of Aloe species $(r=0.73, p=0.267)$. Aloe lateritia Engl. and $A$. secundiflora Engl. were commonly found in Kilimanjaro, Tanga and Mara regions, and together with $A$. duckeri Christian were mentioned for 25, 23 and 24 uses, respectively and some uses were similar among species (Fig. 4). The three species that were never mentioned by any of our respondents, i.e., A. boscawenii, A. confusa Engl. and one unidentified Aloe species, were not known to respondents even when they were shown a freshly collected specimen.

The leading uses of Aloe species were treating malaria in humans $(20 \%)$, followed by treating Newcastle disease in chicken (19\%), and then treating stomachache $(7 \%)$, wounds, hernia, typhoid and ringworm in humans (Supplementary Data Table S2). In Rombo District, planting Aloe (A. volkensii) in a banana field is believed to increase banana yields.

Over half $(58 \%)$ of respondents said they walk less than $1 \mathrm{~km}$ to find Aloe species. The most common preparation of Aloe was by cutting and soaking the leaves in water (48\%), followed by boiling ( $26 \%)$ and finally squeezing out the gel (16\%). The preferred method of administering Aloe for treating diseases was through ingestion ( $80 \%)$, followed by direct application on the skin and wounds (17\%). Almost all $(97 \%)$ of the respondents claimed that the use of Aloe species cured illnesses completely. A total of 171 respondents $(72 \%)$ reported no side effects during the treatment process while $28 \%$ of respondents reported diarrhoea or vomiting after Aloe ingestion.

\section{Conservation of Aloe populations by local people}

Out of all respondents, $81 \%$ said they used only Aloe leaves, while $11 \%$ interchangeably used both leaves and the entire plant (leaves, stem and roots). Among 
those who harvested the entire plant, $72 \%$ harvested only one individual plant per use while $28 \%$ harvested more than three individuals at a time. Most respondents $(88 \%)$ collected Aloe plants from the wild while about a fifth (22\%) cultivated them on farms and in homegardens. Most (98\%) of the plantings of Aloes were done by propagating seedlings while only $2 \%$ used the stem. Two-thirds $(64 \%)$ of the respondents thought that there was no need to cultivate Aloes because they claimed that its availability in the wild was assured if good harvesting techniques were observed.

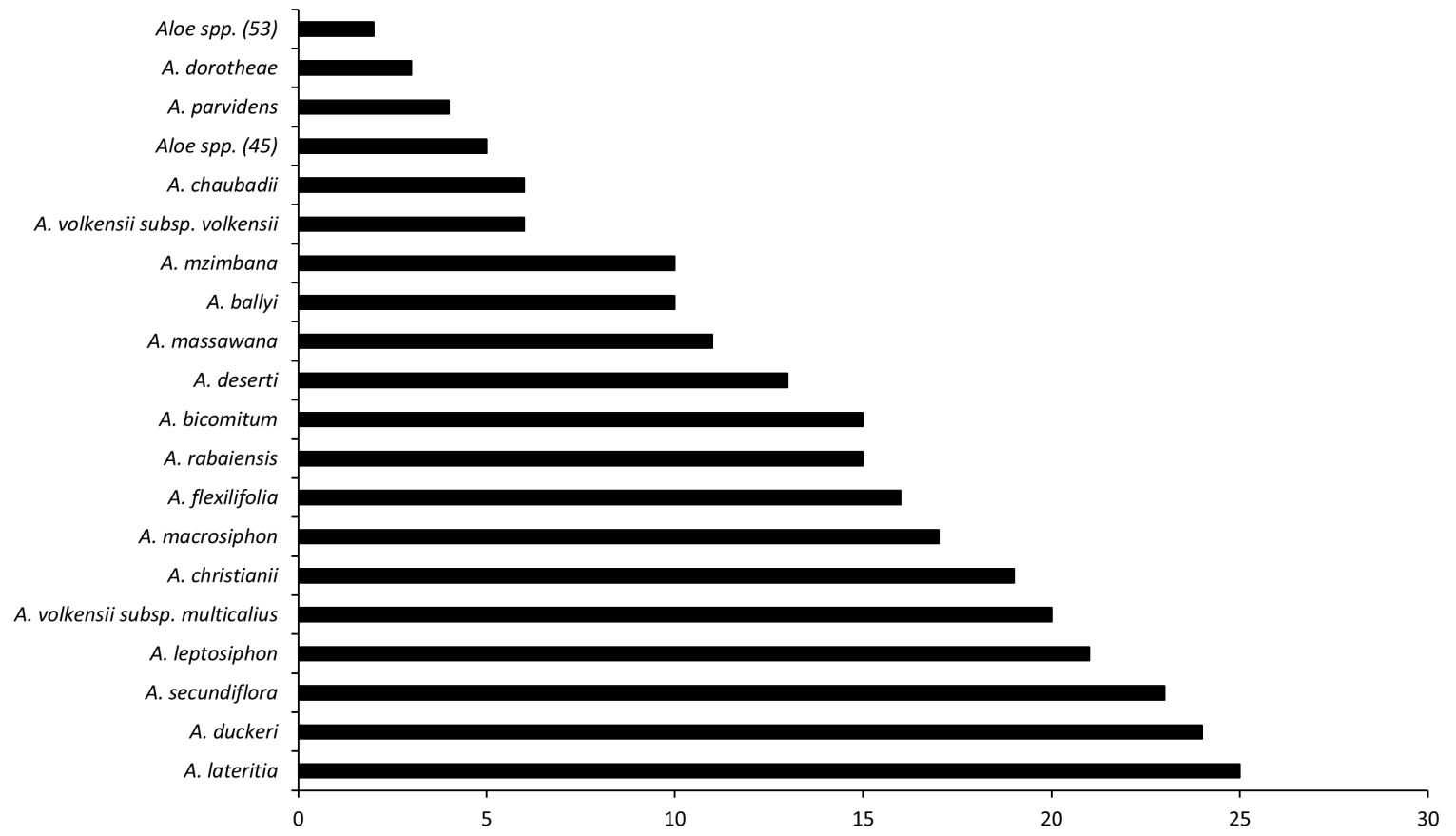

Figure 4. Aloe species and their number of uses as mentioned by the 236 respondents across the four study regions within Tanzania. See also supplementary Table S1 and S2.

Of all respondents, $78 \%$ claimed that Aloe populations have decreased over the past five years, while a few $(7 \%)$ said their abundance was the same today as in the past or had increased $(6 \%)$. Over one-third $(39 \%)$ of respondents claimed that Aloe plants were intermediate in availability while $35 \%$ said the Aloe species were still abundant in the wild. About a quarter (23\%) of respondents thought these species were difficult to find and $3 \%$ claimed some species such as $A$. ballyi in Kisiwani, Kilimanjaro region, and $A$. volkensii in Kideleko, Tanga region, were locally extinct. According to one respondent, the stem (miatini) of the rare species $A$. ballyi in Kisiwani ward in of Kilimanjaro region, was collected only opportunistically from the wild for making local beer. The perception of a general decline in Aloe populations were not significantly correlated with the age of the respondent $(Z=-0.524, p=0.600)$ nor to the number of uses of Aloes ( $p=0.099, H=5.058$ ). Anthropogenic activities, e.g., clearing land for agricultural purposes, were reported to lead to the decline in Aloe species availability (Table 2).

Table 2. Percentage of respondents who cited each threat as a factor in declining Aloe populations.

\begin{tabular}{llllll}
\hline Threat factor & $\begin{array}{l}\text { Kilimanjaro } \\
\mathbf{\%}(\mathbf{n = 5 6})\end{array}$ & $\begin{array}{l}\text { Serengeti } \\
\mathbf{\%}(\mathbf{n = 2 2})\end{array}$ & $\begin{array}{l}\text { Tanga } \\
\mathbf{\%}(\mathbf{n = 9 1})\end{array}$ & $\begin{array}{l}\text { Katavi/Rukwa } \\
\mathbf{\%}(\mathbf{n = 6 7})\end{array}$ & $\begin{array}{l}\text { Total } \\
\mathbf{\%}(\mathbf{n = 2 3 6})\end{array}$ \\
\hline Agriculture & 41 & 66 & 27 & 40 & \\
Climate change & 24 & 6 & 28 & 4 & \\
Fire & 0 & 3 & 17 & 32 & \\
Livestock & 2 & 0 & 1 & 10 & \\
Over-harvesting & 17 & 0 & 9 & 6 & \\
Settlement & 0 & 25 & 16 & 6 & \\
Wild animals & 16 & 0 & 2 & 1 & \\
\hline
\end{tabular}


Wild and domestic animals were also mentioned by locals as a threat to Aloe plants (Fig. 5). In the Kilimanjaro region, elephants were mentioned as feeding and trampling tall Aloes ( $A$. ballyi and $A$. volkensii) in wards close to protected areas (e.g., Mkomazi National Park, Lake Chala and Kilimanjaro National Park). In the Tanga region, monkeys were reported to eat and destroy $A$. lateritia while in Katavi and Rukwa regions, beetles and livestock (cattle and goats) were mentioned and confirmed visually in destroying A. duckeri and Aloe christianii. Reynolds. The need for land to build infrastructure and settlements was also cited as causing mortality of Aloe plants; this factor was of particular note by respondents in the Serengeti region. According to one government official, respondents who cultivated Aloes species received subsidies during Serengeti road construction. We were able to observe many of the factors that respondents cited as threats to Aloes; however, we did not encounter any wild animal species that people claimed to be abundant in the Kilimanjaro region or the Serengeti district. Only four respondents $(2 \%)$ reported that Aloe species trade was low in their areas; the majority $(98 \%)$ claimed that there was no trade of Aloe species. The latter is supported by the low prices for Aloe leaves that we observed in the market: prices ranged from 100 TSh to 1,000 TSh per kg (US\$ 0.04 - 0.43).

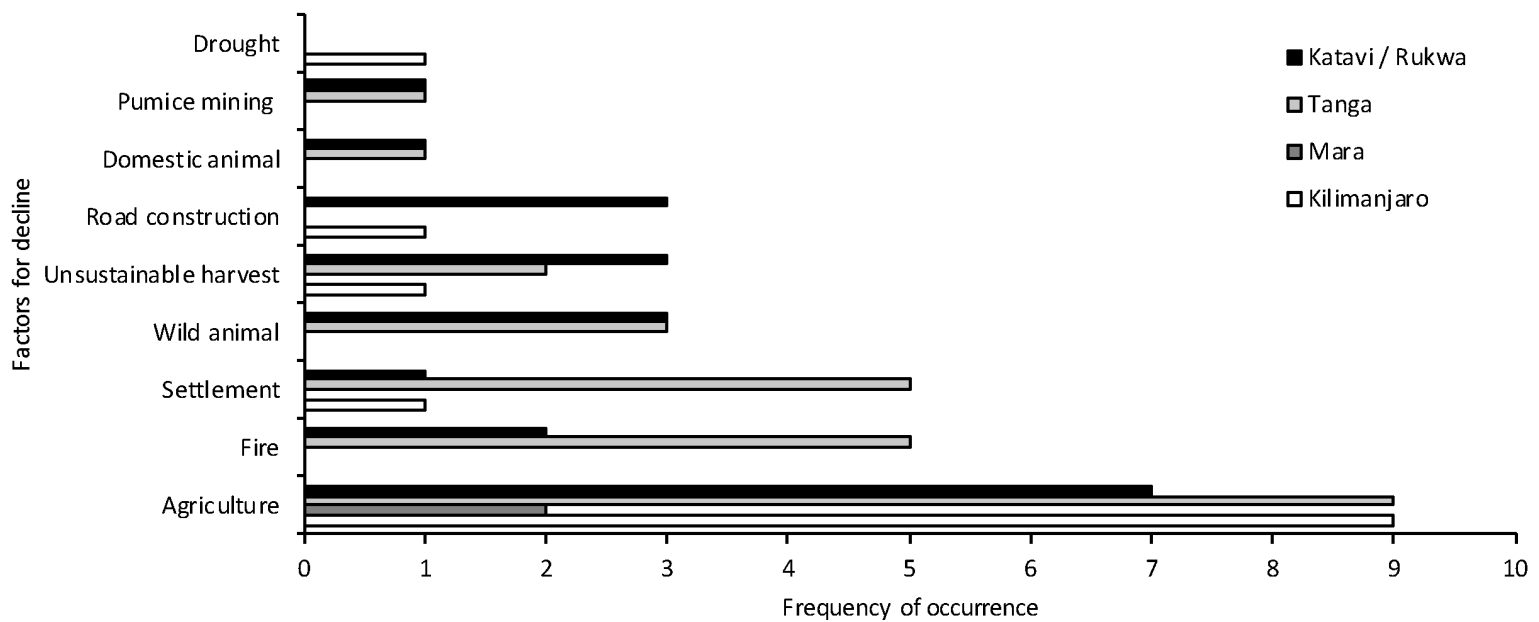

Figure 5. Factors for a potential decline of Aloe species based on field observations (in \% of occurrence) from all four study regions within Tanzania.

\section{Discussion}

Generally, the genus Aloe has had a positive effect on human wellbeing in our study area, given its multiple uses ranging from medicinal use, local beer brewing to simply acting as an ornamental plant. The use of Aloe species has been recognized worldwide (Bjorå et al. 2015; Grace et al. 2008; Manvitha and Bidya 2014; Van Wyk 2013) and Tanzania can, therefore, use its great biodiversity of Aloe species to benefit its people if the utilization can be done in a sustainable way.

\section{Folk taxonomy of Aloe species}

Most respondents from our study regions were able to distinguish Aloe species that were locally present. The locals were also able to differentiate Aloe species from the morphologically similar genus Agave based on the presence of spines along the leaf edges in Aloes and their absence in Agave species, e.g., Agave sisalana Perrine. Confusing these two genera dates back to at least the $17^{\text {th }}$ century, when Agave had been considered to be part of the Aloe family (Bogler et al. 2005). In our study system, folk taxonomy used the same principle that is applied in scientific binomial nomenclature (Berlin. 1973), although names were more strongly based on prominent vegetative structures. The primary name (in this case Kithapa $=$ Aloe) included all species in the genus and secondary names (kietha or kidori = tall or short, respectively) often identified a species or at least similar species. Similar naming systems have been reported in studies of other species and in other geographic areas (Berlin et al. 1966; Berlin 1973), who also hypothesized that folk taxonomy is universal among cultures. In our study, knowledge of folk taxonomy is possibly in decline since most people particularly young ones referred to Aloe species as 'Aloe vera' rather than using local names. The decline of knowledge of folk taxonomy in this case might be due to global importance of Aloe vera products. This is now representing the "common name" for any Aloe species that is encountered (Otieno et al. 2015). Furthermore, urbanization, spread of medical facilities and a formal education 
system may be contributing to less local knowledge (Srithi et al. 2009; Amir et al. 2019) and might replace the use of folk taxonomy. There is a trend of fewer young people being exposed to Aloe species in their natural habitats and few young Tanzanians accompany those with knowledge of folk taxonomy (i.e., grandfathers, fathers and, sometimes, mothers) when they are collecting or working in areas with native plants (Sõukand \& Kalle 2011).

\section{General uses of Aloe species}

In our study, traditional knowledge was more common in older respondents. This highlights the risk that this knowledge might be rapidly vanishing as also other studies have found (Amir et al. 2019; Srithi et al. 2009). Further, we found that men were more involved in the transfer of ethnobotanical knowledge and collecting of Aloes in the wild than women. This might be a reflection of the traditional role men play in the collection of herbal medicines from the wild (Cunningham 1993; Van Hoang et al. 2008; Torres-Avilez et al. 2016).

The two Aloe species ( $A$. lateritia and $A$. secundiflora) that were most commonly used by our respondents were widely distributed in Kilimanjaro, Mara and Tanga regions. Similarly, $A$. duckeri was found in most parts of Katavi and Rukwa regions, where it was commonly used in traditional medicine. These three commonly used Aloe species are a succulent rather than a grassy form, and other studies showed that this Aloe form was preferred (Bjorå et al. 2015; Grace et al. 2015). In our study, the Aloe species were most commonly used in traditional human and veterinary medicine but there were some distinctions depending on the region. For instance, in the Tanga region, use was influenced by the taste, i.e., Aloe volkensii was referred to as "true Aloe" and was preferred for medicinal purposes because of its bitter taste. Similarly, in Kenya, $A$. lateritia is not preferred for medicinal use due to its lack of a bitter taste (Bjorå et al. 2015). The stems of the tall Aloes were an important ingredient in beer brewing, which might have some medicinal effects. For example, Aloe vera wine was found to have antibacterial effects on pathogenic bacteria including Salmonella typhimurium, Staphylococcus aureus and Escherichia coli (Trivedi et al. 2012). Many Aloe species in this study were used for similar purposes as in other areas of East Africa (Table 3; Amir et al. 2019, Bjorå et al. 2015, Grace 2011, Wabuyele 2006). However, in this study, we report the usage of A. mzimbana, $A$. volkensii spp. volkensii, $A$. leptosiphon, $A$. parvidens and $A$. bicomitum for the first time in East Africa (Table 3 and Supplementary Data Table S2). Not a single Aloe species was mentioned to occur in all five studies that had been reported (Table 3), which might be related to the strong endemism of Aloe species (Wabuyele et al. 2006; Reynolds 2004).

Most respondents indicated that they use Aloe species based on their morphological structures, although locals mentioned that at times, it is difficult for local people to distinguish poisonous from nonpoisonous species. For example, A. ballyi, a poisonous species (Reynolds. 2004), looks similar to A. volkensii, a non-poisonous and commonly used species. Thus, confusing of these two species may threaten the health of consumers. The misidentification of plant species either from the same family or different families have been reported to result in kidney injury (Colson \& De Broe. 2005) and sometimes even death (Colombo et al. 2009; Furer et al. 2011; Ndhlala et al. 2013). Furthermore, an overdose of some medicinal Aloe species can result in electrolyte imbalances, low blood sugar levels and even death (Surjushe et al. 2008).

Our study showed that the use of Aloe species has not yet led to a decline in population sizes. These results may stem from the behavior of respondents as most people (89\%) preferred to harvest only a few leaves rather than stems and roots for treating diseases. A lack of a decline has also been observed in other studies of Aloe (Amir 2019; Kidane et al. 2014). An exception to stable populations may be for $A$. ballyi and $A$. volkensii for making local beer and $A$. leptosiphon for medicinal purposes. If these three species continue to see declining populations, it may be necessary to reduce and control the harvest of plant parts. Respondents and our observations also showed that some species, like the endemic $A$. boscawenii, are not frequently used, but they are often uprooted, burned or destroyed. This species and other endemics, which are similarly at risk of extinction, should be given high conservation priority. The majority of respondents $(81 \%)$ were able to access Aloe species within a radius of up to $1 \mathrm{~km}$ from their homes, suggesting that most common Aloe species are still readily available. A plant species is considered to be abundant if a collector has to move only a short distance to find an individual of that species (Castle et al. 2014). However, the clearing of areas with a high abundance of medicinal plants for development purposes has been found to increase the distance and time a collector devotes to searching for a particular plant (Castle et al. 2014; Magoro et al. 2010). We found that the best time for collecting flowering voucher specimens of Aloes in Tanzania was immediately after any of the two rainy seasons in the regions (February to April and June to July, respectively), and this was also mentioned by our respondents. This finding corresponds with 
that of other studies, which indicated that flowering in most Aloe species is linked to climatic patterns (Forbes et al. 2009; Symes 2017).

\section{Aloe population trends and conservation}

Aloe species in our study sites across Tanzania were widely distributed, and many species were still locally available and well known by local people. However, there has been little cultivation of Aloe species. Conserving the species by cultivating it ex-situ reduces pressure on the wild populations (Cocroft 2005; Schippmann et al. 2005). However, in a study on ethno-veterinary medicinal plants in the North West Province of South Africa (van der Merwe et al. 2001), traditional healers claimed that cultivated medicinal plants were less effective in treating ailments compared to wild counterparts. This opinion could potentially prevent lowering pressure on wild populations. Respondents in this study pointed out that unsustainable harvesting practices were detrimental to the wellbeing of wild populations of $A$. ballyi and $A$. volkensii and may have caused their local extinction in Kisiwani and in Kideleko wards, respectively (Fig. 5). Additionally, overharvesting might be the main cause for the local extinction of $A$. volkensii, as we observed in Kideleko ward. The effect of fire has also been mentioned to be more harmful to the Aloe seedlings and juveniles while the mature individuals are fire-tolerant (Cousins and Witkowski 2012).

Furthermore, local extinction of individual species might cause people to shift their preference to other species, thus, further aggravating the conservation of Aloes in the area. The general decline of Aloe populations in the wild mentioned by our respondents highlights the importance of conservation actions that must be taken to ease the pressure on wild populations. Domestic and wild animals such as goats, cattle, elephants and beetles were mentioned by respondents and also observed by us in the field to destroy Aloe species and their wild habitat. This has been previously observed by Bhaludra (2013) and Breebaart et al. (2002). Elephants (Cousins et al. 2013; Wiseman. 2001) have similarly been reported to contribute to high levels of destruction of Aloes in South Africa. However, in addition to damaging plants, some plant-insect interactions are important in the lifecycle of Aloes. For instance, insects can also be crucial for pollination; $A$. plicatilis (L.) Mill. is pollinated by insects such as honeybees (Apis mellifera_ $\mathrm{L}$ ) and perhaps monkey beetles (Scelophysa trimeni (Péringuey, 1902)) (Cousins et al. 2013).

\section{Conclusion}

Our study shows that species in the genus Aloe have multiple health and medicinal uses across Tanzania. These results indicate the need for pharmacological studies to determine the type of chemical compounds found in Aloe extracts for potential clinical and commercial application. However, to ensure the future availability of Aloe species, given their high medicinal value, conservation needs must be addressed. Our study has shown that there is a need to train local communities and formulate policies on sustainable harvesting techniques of plants in the wild. Since we found that the cultivation of medicinal Aloe species was not common, there is a need to train local people on domestication techniques so as to reduce pressure on wild Aloe populations. Although Aloe plants and plant parts were of low commercial value in the study area, local authorities should control their harvest by traditional healers as well as registered and unregistered companies. Failing to take these conservation activities could have detrimental effects on the abundance of a number of species in the genus.

\section{Declarations}

Ethics approval and consent to participate: Permits to conduct this research was acquired from all the districts visited and prior informed consent was obtained from all the respondents. The study was approved by the Research Ethics Committee at Nelson Mandela African Institution of Science and Technology.

Consent for publication: This manuscript does not contain any data on an individual person and further consent for publication is not required.

Availability of data and materials: All the data are in this manuscript.

Competing interests: The authors declare that they have no competing interests.

Funding: Financial support was provided by CREATES (Centre for Research, Agricultural Advancement, Teaching Excellence and Sustainability) through the World Bank as a loan to the Tanzanian government.

Authors' contributions: SAA, HdB, RM and ACT conceived the research. SAA was responsible for field research and interviews. SAA identified the herbarium vouchers; SAA, HdB, RM and ACT processed the data. SAA, HdB, RM and ACT contributed to the manuscript. All authors have read and approved the final manuscript. 
Table 3. Uses of Aloe species recorded in our study $(\sqrt{ })$ and according to five other studies $(a-e)$ conducted in East Africa.

\begin{tabular}{|c|c|c|c|c|c|c|c|c|c|c|c|c|c|c|c|c|c|c|c|c|c|}
\hline \multirow[b]{2}{*}{ Scientific name } & \multicolumn{17}{|c|}{ Human ailments } & \multicolumn{3}{|c|}{ Animal ailments } & \multirow[b]{2}{*}{ 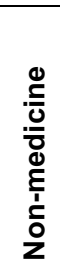 } \\
\hline & $\begin{array}{l}\text { 홍 } \\
\text { 음 }\end{array}$ & 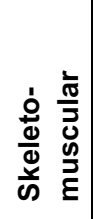 & 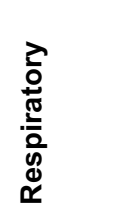 & $\begin{array}{l}\mathscr{n} \\
\stackrel{0}{0} \\
\frac{\mathscr{D}}{0} \\
0\end{array}$ & 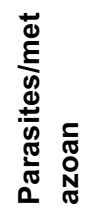 & 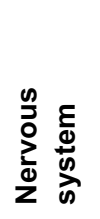 & 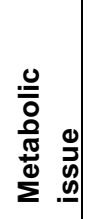 & 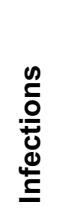 & 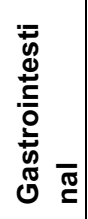 & 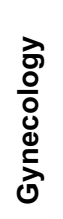 & 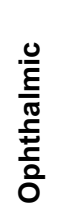 & $\begin{array}{l}\text { 인 } \\
\text { 눈 }\end{array}$ & $\begin{array}{l}\frac{0}{8} \\
\frac{0}{0} \\
\frac{\pi}{\pi} \\
\frac{5}{0} \\
0\end{array}$ & 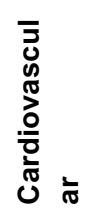 & 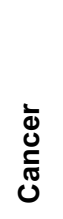 & 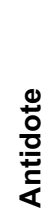 & 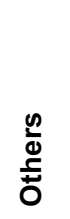 & 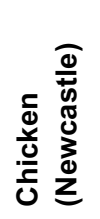 & $\sum_{0}^{n}$ & 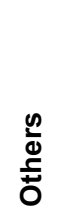 & \\
\hline A. ballyi & & $\sqrt{ }$ & $\sqrt{ }$ & & & & & $\sqrt{ }$ & $\sqrt{ }$ & & & $\sqrt{ }$ & & $\sqrt{ }$ & & & $\sqrt{, d}$ & & & & \\
\hline A. bicomitum & & & $\sqrt{ }$ & & & & & $\sqrt{ }$ & $\sqrt{ }$ & & & & & $\sqrt{ }$ & & $\sqrt{ }$ & & $\sqrt{ }$ & & & \\
\hline A. chabaudii & & & & & & $\sqrt{ }$ & & $\sqrt{ }$ & $\begin{array}{l}\sqrt{, e}, \\
b\end{array}$ & $\mathrm{e}$ & $\mathrm{b}$ & & & $\sqrt{ }$ & & $\sqrt{ }$ & $\mathrm{b}$ & $\sqrt{ }$ & & & \\
\hline A. christianii & & $\sqrt{ }$ & $\sqrt{ }$ & & $\sqrt{ }$ & $\sqrt{ }$ & & $\sqrt{ }$ & $\sqrt{ }$ & $\begin{array}{l}\mathrm{e}, \\
\mathrm{b}\end{array}$ & & & e & $\sqrt{ }, \mathrm{e}$ & & $\sqrt{ }$ & & $\sqrt{ }$ & & & \\
\hline A. deserti & $\sqrt{ }$ & $\mathrm{d}, \mathrm{e}$ & $\mathrm{d}, \mathrm{e}$ & & & $\sqrt{ }$ & $\mathrm{d}, \mathrm{e}$ & $\begin{array}{l}\sqrt{, d}, \\
e^{-}\end{array}$ & $\sqrt{ }$ & & & $\sqrt{ }$ & $\sqrt{ }$ & $\sqrt{ }$ & & & & $\mathrm{d}, \mathrm{e}$ & $\sqrt{ }$ & d,e & d \\
\hline A. dorotheae & & & & & & & $\sqrt{ }$ & $\sqrt{ }$ & & & & & $\sqrt{ }$ & & & & & $\sqrt{ }$ & & & \\
\hline A. duckerii & & $\sqrt{ }$ & $\sqrt{ }$ & $\sqrt{ }$ & $\sqrt{ }$ & $\sqrt{ }$ & & $\sqrt{ }$ & $\sqrt{ }$ & $\sqrt{ }$ & & & $\sqrt{ }$ & $\sqrt{, b}$ & & $\sqrt{ }$ & & $\sqrt{ }$ & & & \\
\hline A. flexilifolia & & & & & & $\sqrt{ }$ & $\sqrt{ }$ & & $\sqrt{ }$ & $\sqrt{ }$ & & & & $\sqrt{ }$ & $\mathrm{e}$ & & $\sqrt{ }$ & $\sqrt{ }$ & & & \\
\hline A. lateritia & & $\sqrt{ }$ & $\sqrt{ }, \mathrm{d}, \mathrm{e}$ & $\mathrm{b}$ & $\sqrt{ }, \mathrm{d}, \mathrm{e}$ & $\sqrt{ }, \mathrm{d}, \mathrm{e}$ & $\sqrt{ }$ & $\begin{array}{l}\sqrt{ }, \mathrm{d} \\
\mathrm{e}\end{array}$ & $\sqrt{d}$ & $\sqrt{ }$ & d,e & $d$ & $\begin{array}{l}\sqrt{ }, d, \\
e^{-}\end{array}$ & $b, e$ & & $\mathrm{~d}$ & $\sqrt{ }, \mathrm{b}$ & $\sqrt{ }, \mathrm{d}, \mathrm{e}$ & $\mathrm{b}$ & $d, e$ & $d, b$ \\
\hline A. leptosiphon & & $\sqrt{ }$ & $\sqrt{ }$ & $\sqrt{ }$ & & $\sqrt{ }$ & $\sqrt{ }$ & $\sqrt{ }$ & $\sqrt{ }$ & & & & $\sqrt{ }$ & $\sqrt{ }$ & & & & $\sqrt{ }$ & $\sqrt{ }$ & & \\
\hline A. macrosiphon & & & $\sqrt{ }$ & & $\sqrt{ }$ & $\sqrt{ }$ & & $\sqrt{ }$ & $\sqrt{ }, \mathrm{e}$ & $\sqrt{ }$ & & & $\sqrt{ }$ & $\sqrt{ }$ & & & $\mathrm{c}$ & & & & \\
\hline A. massawana & & & & & $\sqrt{ }$ & $\sqrt{ }$ & $\mathrm{b}$ & & $\sqrt{ }$ & & & & & $\sqrt{ }$ & & & & $\sqrt{ }$ & & & \\
\hline A. mzimbana & & & & & $\sqrt{ }$ & & & $\sqrt{ }$ & $\sqrt{ }$ & J & & & $\sqrt{ }$ & $\sqrt{ }$ & & & & $\sqrt{ }$ & & & \\
\hline A. parvidens & & $\sqrt{ }$ & & & & & & $\sqrt{ }$ & & & & & & $\sqrt{ }$ & & $\sqrt{ }$ & & & & & \\
\hline A. rabaiensis & $\sqrt{ }$ & $\sqrt{ }$ & $\sqrt{ }$ & $\mathrm{b}$ & & $\sqrt{ }$ & & $\sqrt{ }$ & $\sqrt{ }$ & & & $\sqrt{ }$ & $\sqrt{c}$ & $\sqrt{ }$ & & & & & $\sqrt{ }$ & & \\
\hline A. secundiflora & $\begin{array}{l}\sqrt{, d}, \\
e\end{array}$ & $\begin{array}{l}\sqrt{, d}, \\
e^{-}\end{array}$ & $\sqrt{, b, d, e}$ & $\mathrm{~b}$ & e & $\begin{array}{l}\sqrt{, b, d}, \\
e^{-}\end{array}$ & $\begin{array}{l}\sqrt{, d}, \\
e^{-}\end{array}$ & $\sqrt{d e}$ & $\begin{array}{l}\sqrt{, b}, \\
d, e\end{array}$ & & $\begin{array}{l}\sqrt{, d}, \\
\mathrm{e}^{-}\end{array}$ & $\begin{array}{l}\sqrt{, a} \\
, d\end{array}$ & $\begin{array}{l}\sqrt{, b}, \\
d, e\end{array}$ & $\begin{array}{l}\sqrt{, b d}, \\
e^{-}\end{array}$ & & & $\sqrt{ }$ & $\begin{array}{l}\sqrt{, b, d}, \\
e^{-}\end{array}$ & $\sqrt{, d}$ & $b, d$ & $\begin{array}{l}\mathrm{b}, \mathrm{c} \\
\mathrm{d}\end{array}$ \\
\hline $\begin{array}{l}\text { A. volkensii subsp. } \\
\text { multicalius }\end{array}$ & & $\sqrt{ }$ & $\sqrt{ }, \mathrm{b}, \mathrm{d}, \mathrm{e}$ & $\mathrm{b}$ & & $\sqrt{ }$ & $\sqrt{, e}$ & $\sqrt{ }$ & $\sqrt{ }$ & & $\sqrt{, e}$ & $\sqrt{, b}$ & $\mathrm{e}$ & $\sqrt{ }, \mathrm{e}$ & & & $\sqrt{ }$ & $\sqrt{ }$ & $\sqrt{ }, \mathrm{d}$ & d & d \\
\hline $\begin{array}{l}\text { A. volkensii subsp. } \\
\text { volkensii }\end{array}$ & & & & & & & $\sqrt{ }$ & $\sqrt{ }$ & $\sqrt{ }$ & & & & & $\sqrt{ }$ & & & & $\sqrt{ }$ & $\sqrt{ }$ & & \\
\hline Aloe sp. (SA 45) & & & & & & $\sqrt{ }$ & & $\sqrt{ }$ & $\sqrt{ }$ & & & & & & & & & $\sqrt{ }$ & & & \\
\hline Aloe sp. (SA 53) & & & & & & $\sqrt{ }$ & & $\sqrt{ }$ & $\sqrt{ }$ & & & & & $\sqrt{ }$ & & & & $\sqrt{ }$ & & & \\
\hline Aloe sp. (SA 87) & & & & & & $\sqrt{ }$ & & & & & & & & & & & & $\sqrt{ }$ & & & \\
\hline
\end{tabular}

NB: Findings in this study $=\sqrt{ }, a=$ Wabuyele et al. 2006, $b=$ Grace et al. 2009, c $=$ Grace 2011, $d=$ Bjorå et al. 2015 and e $=$ Amir et al. 2019 . The diseases were categorized based on the classification of diseases and remedies in ethnomedicine and ethnopharmacology (Staub et al. 2015) 
Acknowledgements: We are grateful to all district authorities for permission to conduct this research in their areas and support shown by the ward and village leaders during the survey. Many thanks to all field assistants.

\section{Literature cited}

Aboelsoud NH. 2010. Herbal medicine in ancient Egypt. Journal of Medicinal Plants Research 4(2):8286. doi:10.5897/JMPR09.013.

Amir HM, Grace OM, Wabuyele E, Manoko MLK. 2019. Ethnobotany of Aloe L. (Asphodelaceae) in Tanzania. South African Jourtnal of Botany doi:10.1016/j.sajb.2019.01.038.

Bennett J, Brown CM. 2000. Use of Herbal Remedies by Patients in a Health Maintenance Organization. Journal of the American Pharmacist Association 40(3):353-358. doi:10.1016/S10865802(16)31082-8.

Berlin B. 1973. Folk Systematics in Relation to Biological Classification and Nomenclature. Annual Review of Ecology and Systematics 4(1):259-271. doi:10.1146/annurev.es.04.110173.001355.

Berlin B, Breedlove DE, Raven PH. 1966. Folk taxonomies and biological classification. Science 154(3746):273-275. doi:10.1126/science.154.3746. 273.

Bhaludra CSS, Bethapudi RR, Murugulla AC, Pullagummi C, Latha T, Venkatesh K, Bheemagani AJ, Pudutha A, Rani AR. 2013. Cultivation, phytochemical studies, biological activities and medicinal uses of Aloe ferox, grandfather of Aloes an important amazing medicinal plant. International Journal of Pharmacology 9(7):405-415. doi:10.3923/ijp.2013.405.415.

Bjorå CS, Wabuyele E, Grace OM, Nordal I, Newton LE. 2015. The uses of Kenyan aloes: An analysis of implications for names, distribution and conservation. Journal of Ethnobiology and Ethnomedicine 11(1). doi:10.1186/s13002-0150060-0.

Bogler DJ, Pires JC, Francisco-Ortega J. 2005. Phylogeny of Agavaceae based on ndhf, rbcl, and its sequences: implications of molecular data for classification. Aliso Rancho St Ana Botanical Garden 22(1):311-326. doi:10.5642/aliso.20062201.26.

Breebaart L, Bhikraj R, O'connor TG. 2002. Impact of goat browsing on Aloe ferox in a South African savanna. African Journal of Range and Forage Science 19(1):77-78. doi:10.2989/10220110209485 777.
Carter S. 1994. Aloaceae: Flora of Tropical East Africa. Royal Botanical Gardens, Kew.

Castle LM, Leopold S, Craft R, Kindscher K. 2014. Ranking tool created for medicinal plants at risk of being overharvested in the wild. Ethnobiology Letters 5(1):77-88. doi:10.14237/ebl.5.2014.169.

Cocroft R. 2005. The Behavioral Ecology of Insect Vibrational Communication. Bioscience. 55:323-334. doi:10.1641/0006-3568(2005)055.

Colombo ML, Marangon K, Locatelli C, Giacchè M. 2009. Hemlock poisoning due to plant misidentification. Journal of Pharmaceutical Sciences and Research 1(4):43-47.

Colson CRD, De Broe ME. 2005. Kidney injury from alternative medicines. Advances in Chronic Kidney Disease 12(3):261-275. doi:10.1016/j.ackd.2005.03. 006.

Cousins SR, Witkowski ETF. 2012. African Aloe ecology: A review. Journal of Arid Environments 85:1-17. doi:10.1016/j.jaridenv.2012.03.022.

Cousins SR, Witkowski ETF, Pfab MF, Riddles RE, Mycock DJ. 2013. Reproductive ecology of Aloe plicatilis, a fynbos tree aloe endemic to the Cape Winelands, South Africa. South African Journal of Botany 87:52-65. doi:10.1016/j.sajb.2013.02.174.

Cunningham AB. 1993. African medicinal plants: Setting priorities in the interface of Consravation and primary healthcare. People Plants Initiatiative 53.

EAM \& CFCPAP. 2009. Aloe boscawenii. Vol. 8235. Aloe boscawenii. The IUCN Red List of Threatened Species 2009: e.T158325A5195623. p.1-8.

Foden W, Midgley GF, Hughes G, Bond WJ, Thuiller W, Hoffman MT, Kaleme P, Underhill LG, Rebelo A, Hannah L. 2007. A changing climate is eroding the geographical range of the Namib Desert tree Aloe through population declines and dispersal lags. Diversity and Distributions 13(5):645-653. doi:10.1111/j.1472-4642.2007.00391.x.

Forbes RW, Craig AJFK, Hulley PE, Parker DM. 2009. Seasonal variation in the avian community associated with an Aloe ferox (Asphodelaceae, Mill.) flowering event in the Eastern Cape, South Africa. Proceedings 12th Pan-African Ornithological Congress 2008.

Furer V, Hersch M, Silvetzki N, Breuer GS, Zevin S. 2011. Nicotiana glauca (Tree Tobacco) IntoxicationTwo Cases in One Family. Journal of Medical Toxicology 7(1):47-51. doi:10.1007/s13181-0100102-x. 
Grace OM. 2011. Current perspectives on the economic botany of the genus Aloe $\mathrm{L}$. (Xanthorrhoeaceae). South African Journal of Botany 77(4):980-987. doi:10.1016/j.sajb.2011.07. 002.

Grace OM, Buerki S, Symonds MRE, Forest F, Van Wyk AE, Smith GF, Klopper RR, Bjorå CS, Neale S, Demissew S, et al. 2015. Evolutionary history and leaf succulence as explanations for medicinal use in aloes and the global popularity of Aloe vera. BMC Evolutionaly Biology 15(1):1-12. doi:10.1186/ s12862-015-0291-7.

Grace OM, Simmonds MSJ, Smith GF, van Wyk AE. 2008. Therapeutic uses of Aloe L. (Asphodelaceae) in southern Africa. Journal of Ethnopharmacology 119(3):604-614. doi:10.1016/j.jep.2008.07.002.

Grace OM, Simmonds MSJ, Smith GF, Van Wyk AE. 2009. Documented utility and biocultural value of Aloe L. (Asphodelaceae): A review. Economic Botany 63(2):167-178. doi:10.1007/s12231-0099082-7.

Van Hoang S, Baas P, Keßler PJA. 2008. Uses and conservation of plant species in a national park - A case study of Ben En, Vietnam. Economic Botany 62(4):574-593. doi:10.1007/s12231-008-9056-1.

Kidane B, Andel T Van, Josephus L, Maesen G Van Der, Asfaw Z. 2014. Use and management of traditional medicinal plants by Maale and Ari ethnic communities in southern Ethiopia. Journal of Ethnobiology and Ethnomedicine 10(46).

Magoro MD, Masoga MA, Mearns MA. 2010. Traditional health practitioners' practices and the sustainability of extinction-prone traditional medicinal plants. International Journal of African Renaiss Studies - Multi-, Inter- Transdisciplinary 5(2):229-241. doi:10.1080/18186874.2010.534842.

Manvitha K, Bidya B. 2014. Aloe vera: a wonder plant its history, cultivation and medicinal uses. Journal of Pharmacognosy and Phytochemistry JPP. 2(25):8588.

Merwe D van der, Swan GE, Botha CJ. 2001. Use of ethnoveterinary medicinal plants in cattle by Setswana-speaking people in the Madikwe area of the North West Province of South Africa. Journal of the South African Veterinary Association 72(4):189196. doi:10.4102/jsava.v72i4.651.

Ndhlala AR, Ncube B, Okem A, Mulaudzi RB, Van Staden J. 2013. Toxicology of some important medicinal plants in southern Africa. Food Chemistry and Toxicology 62:609-621. doi:10.1016/ j.fct.2013.09.027.
Otieno J, Abihudi S, Veldman S, Nahashon M, van Andel T, de Boer HJ. 2015. Vernacular dominance in folk taxonomy: A case study of ethnospecies in medicinal plant trade in Tanzania. Journal of Ethnobiology and Ethnomedicine 11(1). doi:10.1186/1746-4269-11-10.

Pandey R, Mishra A. 2010. Antibacterial activities of crude extract of Aloe barbadensis to clinically isolated bacterial pathogens. Applied Biochemistry and Biotechnology 160(5):1356-1361. doi:10.1007/ s12010-009-8577-0.

Pili K. 2007. Aloe; Beyond Use As Cosmetics. Dar es Salaam Med Students' Journal 15:31-35.

Reynolds T. 2004. Aloe: The genus Aloe. Borea Raton London New York Washington, DC.CRC press.

Reynolds T. 2005. Hemlock alkaloids from Socrates to poison aloes. Phytochemistry 66(12):1399-1406. doi:10.1016/j.phytochem.2005.04.039.

Sarper F, Akaydin G, Şimşek I, Yeşilada E. 2009. An ethnobotanical field survey in the Haymana district of Ankara province in Turkey. Turkish Journal of Biology 33(1):79-88. doi:10.3906/biy-0808-28.

Schippmann U, Cunningham AB, Leaman DJ, Walter S. 2005. Impact of cultivation and collection on the conservation of medicinal plants: Global trends and issues. Acta Horticulturae 676:31-44. doi:10.17660/actahortic.2005.676.3.

Shahzad MN, Ahmed N. 2013. Effectiveness of Aloe vera gel compared with $1 \%$ silver sulphadiazine cream as burn wound dressing in second degree burns. Journal of the Pakistan Medicinal Association 63(2):225-230.

Sõukand R, Kalle R. 2011. Change in medical plant use in Estonian ethnomedicine: A historical comparison between 1888 and 1994. Journal of Ethnopharmacology 135(2):251-260. doi:10.1016/j.jep.2011.02.030.

Srithi K, Balslev $\mathrm{H}$, Wangpakapattanawong $\mathrm{P}$, Srisanga P, Trisonthi C. 2009. Medicinal plant knowledge and its erosion among the Mien (Yao) in northern Thailand. Journal of Ethnopharmacology 123(2):335-342. doi:10.1016/j.jep.2009.02.035.

Staub PO, Geck MS, Weckerle CS, Casu L, Leonti M. 2015. Classifying diseases and remedies in ethnomedicine and ethnopharmacology. Journal of Ethnopharmacology 174:514-519. doi:10.1016/ j.jep.2015.08.051. 
Surjushe, A., Vasani, R., \& Saple DG. 2008. Aloe vera: a short review. Indian Journal of Dermatology 53(4):163-168.

Symes CT. 2017. Notes on the flowering and pollination of the endemic grassland Aloe reitzii var . reitzii (Asphodelaceae). Bothalia. 47(1):5-9. doi:10.4102/abc.v47i1.2215.

Taylor P, Bolus C, Hoffman T, Todd S, Powell E, Clark B. 2010. The distribution and population structure of Aloe pillansii in South Africa in relation to climate and elevation The distribution and population structure of Aloe pillansii in South Africa. Transactions of the Royal Society of South Africa (October 2014) 59(2) 37-41. doi:10.1080/00359190409519174.

Tomov N. 2018. Preserving the Pontiff : an Account of the Body Preservation Methods Used by the Roman Catholic Church. Acta Morphologica Anthropologica 2(July):1-2.

Torres-Avilez W, Medeiros PM de, Albuquerque UP. 2016. Effect of Gender on the Knowledge of Medicinal Plants: Systematic Review and MetaAnalysis. Evidence-Based Complement Alternative Medicine 2016:1-13. doi:10.1155/2016/6592363.

Trivedi N, Rishi P, Soni SK. 2012. Production of a herbal wine from Aloe vera gel and evaluation of its effect against common food borne pathogens and probiotics. International Journal of Food Fermentation Technology 2(2):157-166.

Veríssimo EP. 2016. Aloe species in colorectal cancer therapy: Friend or Foe? Aloe species in colorectal cancer therapy: Friend or Foe? Eduarda Pimenta Veríssimo. Universidade De Lisboa.

Wabuyele E. 2006. Studies on East African Aloe Species: Aspects of Taxonomy, Conservation and Ethnobotany. University of Oslo, Norway.

Wabuyele E, Kyalo S. 2008. WG 3 - Succulents and Cycads. Case Study 1 - Sustainable use of East African Aloes: The case of commercial Aloes in Kenya. Int Expert Work CITES Non-Detrimental Find.:1-17. http://www.conabio.gob.mx/institucion/cooperacion_ internacional/TallerNDF/wfunctioning.html.

Wabuyele E, Kyalo S, Africa E. 2008. Sustainable Use of East African Aloes: the case of commercial Aloes in Kenya. Journal of Ethnobiology and Ethnbomedicine 11:82. doi:10.1186/s13002-0150060-0

Wabuyele E, Sletten Bjora C, Nordal I, Newton LE. 2006. Distribution, diversity and Conservation of the Genus Aloe in Kenya. Journal of East African Natural History 95(2):213-225. doi:10.2982/00128317(2006)95\%255B213:DDACOT\%255D2.0.CO\% $5 \mathrm{Cn} 2$.

Warren R, Price J, Fischlin A, De S, Santos N, Midgley G. 2010. Increasing impacts of climate change upon ecosystems with increasing global mean temperature rise. Climatic Change 106:141177. doi:10.1007/s10584-010-9923-5.

Weckerle CS, de Boer HJ, Puri RK, van Andel T, Bussmann RW, Leonti M. 2018. Recommended standards for conducting and reporting ethnopharmacological field studies. Journal of Ethnopharmacology 210:125-132. doi:10.1016/ j.jep.2017.08.018.

Wiseman R. 2001. Woody vegetation change in response to browsing in Ithala Game Reserve, South Africa. University of Cape Town, South Africa.

Van Wyk B-E. 2013. Uses of Aloe in traditional and modern medicine. ALOE. 50:53-57.

Van Wyk BE. 2011. The potential of South African plants in the development of new medicinal products. South African Journal of Botany 77(4):812-829. doi:10.1016/j.sajb.2011.08.011.

Yebpella GG, Adeyemi HMM, Hammuel C, Magomya AM, Agbaji AS, Okonkwo EM. 2011. Phtyochemical screening and comparative study of antimicrobial activity of Aloe vera various extracts. African Journal of Microbiological Research 5(10):1182-1187. doi:10.5897/AJMR10.818. 
Supplementary Data Table S1. Herbarium voucher specimens SA1-SA186 and their scientific names, vernacular names of Aloe spp., as well as their meaning in English and descriptions as given by respondents $(n=236)$ in the study area within Tanzania.

\begin{tabular}{|c|c|c|c|c|}
\hline Scientific name & Vernacular name & Tribe & Translation & Informant description \\
\hline \multirow{2}{*}{ Aloe ballyi Reynolds (SA-172, 180) } & Kithapa/Kisapa & Pare & Aloe & Tall Aloe \\
\hline & Kithapa/Kisapa cha vujawa & Pare & Aloe & Tall Aloe \\
\hline Aloe bicomitum L.C.Leach & Tembosha/ltemboshya & Fipa & Aloe & $\begin{array}{l}\text { Spotted Aloe from the lake } \\
\text { side }\end{array}$ \\
\hline \multirow[t]{2}{*}{$(\mathrm{SA}-137,145)$} & Tembosha/ltemboshya & Lungu & Aloe & $\begin{array}{l}\text { Sword like Aloe from the lake } \\
\text { side }\end{array}$ \\
\hline & Tembosha/ltemboshya & Gongwe & Aloe & Green Aloe \\
\hline Aloe christianii Reynolds & Tembwisha & Pimbwe & Aloe & Green Aloe \\
\hline \multirow{3}{*}{$(\mathrm{SA}-106,108,110,112,113,125,132,133,138)$} & Igaka/lughaka & Sukuma & Aloe & Green Aloe \\
\hline & Tembosha/ltemboshya & Nyiha (Mbozi) & Aloe & $\begin{array}{l}\text { Green Aloe /unspotted Aloe } \\
\text { with sharp spine like sword }\end{array}$ \\
\hline & Tembosha/ltemboshya & Fipa & Aloe & Green Aloe \\
\hline \multirow{2}{*}{ Aloe deserti A.Berger (SA-181) } & Kithapa/Kisapa & Kamba & Aloe & Tall Aloe \\
\hline & Kithapa/Kisapa & & Aloe & Short spotted Aloe \\
\hline Aloe dorotheae A.Berger (SA-47, 48, 49, 69, 76) & Kikoli chekundu & Zigua & Red Aloe & Red with spots \\
\hline \multirow{4}{*}{$\begin{array}{l}\text { Aloe duckeri Christian (SA-114, 116, 117, 118, 122, } \\
124,126,128,129,131,134,140,142,148)\end{array}$} & Ivata or Amavata (plural) & $\begin{array}{l}\text { Nyika } \\
\text { (Sumbawanga) }\end{array}$ & Aloe & Huge spotted Aloe \\
\hline & Igaka/Lughaka & Sukuma & Aloe & Huge spotted Aloe \\
\hline & Tembwisha & Pimbwe & Aloe & Spotted and Green Aloe \\
\hline & Tembosha/ltemboshya & Fipa, Nyika & Aloe & Huge spotted Aloe \\
\hline \multirow[t]{2}{*}{ Aloe flexilifolia Christian (SA-34, 37) } & Kovongo ya majani marefu & Sambaa & $\begin{array}{l}\text { Aloe with long } \\
\text { leaves }\end{array}$ & Hanging on cliff surface \\
\hline & Kovongo & Sambaa & Aloe & Aloe with dark leaves \\
\hline \multirow{5}{*}{$\begin{array}{l}\text { Aloe lateritia Engl. (SA-28, 29, 31, 39, 42,44, 46, 67, } \\
73,74,77,82,85,88,155)\end{array}$} & Likulakula & Bena & Aloe & Short spotted Aloe \\
\hline & Ratuni/Inaboru & Chagga & Aloe & Short Aloe with wide leaves \\
\hline & Kovongo baridi & Sambaa & Cool Aloe & $\begin{array}{l}\text { Spotted and soft, not a true } \\
\text { Aloe vera. }\end{array}$ \\
\hline & Kovongo & Sambaa & Aloe & Spotted Aloe with thin leaves \\
\hline & Ekighaka/Kighaka & Kurya & Aloe & Spotted Aloe \\
\hline \multirow{2}{*}{$\begin{array}{l}\text { Aloe leptosiphon A.Berger (SA-20, 21, 22, 23, 30, } \\
32,33,35,36,41)\end{array}$} & Katani ya dawa & Sambaa & Medicinal sisal & $\begin{array}{l}\text { Spines at the side, bitter } \\
\text { taste }\end{array}$ \\
\hline & Kovongo kali yamakungu & Sambaa & $\begin{array}{l}\text { Bitter Aloe } \\
\text { from the cliff }\end{array}$ & Spots, bitter taste \\
\hline
\end{tabular}




\begin{tabular}{|c|c|c|c|c|}
\hline & Kovongo & Sambaa & $\begin{array}{l}\text { Aloe with } \\
\text { sports }\end{array}$ & $\begin{array}{l}\text { Used as grease for locally } \\
\text { made bicycles }\end{array}$ \\
\hline & Kashaza fupi & Sambaa & Short Aloe & Designating ancestor's grave \\
\hline & Kovongo ya majani mafupi & Sambaa & $\begin{array}{l}\text { Aloe with short } \\
\text { leaves }\end{array}$ & Short Aloe \\
\hline & $\begin{array}{l}\text { Katani jamakungu or Katani } \\
\text { za kwenye majabali }\end{array}$ & Sambaa & $\begin{array}{l}\text { Aloe from the } \\
\text { cliff }\end{array}$ & Bitter Aloe with spots \\
\hline & Katani ya dawa & Sambaa & $\begin{array}{l}\text { Sisal for } \\
\text { medicine }\end{array}$ & $\begin{array}{l}\text { Aloe, which turns red in hot } \\
\text { areas and green in cold } \\
\text { areas }\end{array}$ \\
\hline Aloe macrosiphon Baker (SA- 51, 57, 59, 62) & Ekighaka/Kighaka & Kurya & Aloe & $\begin{array}{l}\text { Short spotted Aloe, } \\
\text { sometimes turns red }\end{array}$ \\
\hline \multirow{2}{*}{$\begin{array}{l}\text { Aloe massawana Reynolds (SA-27, 83, 90, 92, 98, } \\
\text { 163) }\end{array}$} & Shubiri & Digo & \multirow{2}{*}{ Aloe } & Short spotted Aloe \\
\hline & Kikoli & Zigua & & Huge green spotted Aloe \\
\hline \multirow{2}{*}{$\begin{array}{l}\text { Aloe mzimbana Verd. \& Christian (SA-120, } \\
127,130)\end{array}$} & Tembosha/ltemboshya & Fipa & Aloe & $\begin{array}{l}\text { Small spotted Aloe from the } \\
\text { cliff }\end{array}$ \\
\hline & Ivata or Amavata (plural) & Nyika & Aloe & $\begin{array}{l}\text { Small spotted Aloe from the } \\
\text { cliff }\end{array}$ \\
\hline \multirow{4}{*}{$\begin{array}{l}\text { Aloe parvidens M.G.Gilbert \& Sebsebe (SA- 171, } \\
\text { 174) }\end{array}$} & Kinabwele & Pare & Aloe & Spotted Aloe \\
\hline & Kithapa/Kisapa & Pare & Aloe & Spotted Aloe \\
\hline & Kinabwele & Pare & Aloe & Spotted Aloe \\
\hline & Kithapa/Kisapa & Pare & Aloe & Spotted Aloe \\
\hline \multirow[t]{2}{*}{ Aloe rabaiensis Rendle (SA-176-179, 182, 183) } & Ratina & Muarusha & Aloe & Spotted Aloe \\
\hline & Kithapa/Kisapa & Pare & Aloe & Short spotted Aloe \\
\hline \multirow{10}{*}{ Aloe secundiflora Engl. (SA-150, 152, 169, 184) } & Olsukuroi miguu mingi & Maasai & $\begin{array}{l}\text { Aloe with } \\
\text { many legs }\end{array}$ & Short unspotted Aloe \\
\hline & Romomoi & Muarusha & Aloe & Short Aloe with wide leaves \\
\hline & Olsukuroi & Meru & Aloe & Short Aloe with wide leaves \\
\hline & Olsukuroi & Maasai & Aloe & Short Aloe with wide leaves \\
\hline & Inaboru & Chaga & Aloe & Short Aloe \\
\hline & Olsukuroi miguu mingi & Maasai & $\begin{array}{l}\text { Aloe with } \\
\text { many legs }\end{array}$ & Short unspotted Aloe \\
\hline & Romomoi & Muarusha & Aloe & Short Aloe with wide leaves \\
\hline & Olsukuroi & Meru & Aloe & Short Aloe with wide leaves \\
\hline & Kinabwele & Pare & Aloe & Unspotted Aloe \\
\hline & Olsukuroi & Maasai & Aloe & Short Aloe with wide leaves \\
\hline \multirow{2}{*}{$\begin{array}{l}\text { Aloe volkensii Engl. (SA-24, 68, 84, 89, 91, 94, 96, } \\
\text { 160, 161, 162, 166, 168, 175, 185,186) }\end{array}$} & Mangoda & Sambaa & Aloe & Tall Aloe \\
\hline & Ekighaka/Kighaka & Kurya & Aloe & Tall with spots when young \\
\hline
\end{tabular}

Published:30 December 2020

http://dx.doi.org/10.32859/era.18.43.1-28 
Ethnobotany Research and Applications

\begin{tabular}{|l|l|l|l|l|}
\multirow{5}{*}{} & Mangoda & Sambaa & Aloe & Tall Aloe \\
\cline { 2 - 5 } & Kithapa/Kisapa cha vujawa & Pare & Aloe & Tall Aloe \\
\cline { 2 - 5 } & Olsukuroi mguu mmoja & Maasai & Aloe with one & Tall Aloe \\
\cline { 2 - 5 } & $\begin{array}{l}\text { Kashaza ndefu or } \\
\text { Maoza/oza }\end{array}$ & Sambaa & Tall Aloe & Tall Aloe \\
\cline { 2 - 5 } & Isale la njovu (tembo) & Chaga & Aloe & Tall Aloe \\
\cline { 2 - 5 } & Shubiri pori & Digo & Wild Aloe & Tall Aloe \\
\cline { 2 - 5 } & Likulakula & Bena & Aloe & Tall Aloe \\
\cline { 2 - 5 } & Ratuni & Chaga & Aloe & Tall Aloe with wide leaves \\
\cline { 2 - 5 } & Inaboru & Chaga & Aloe & Tand short Aloe \\
\hline $\begin{array}{l}\text { Aloe (Unidentified) } \\
\text { (SA-45) }\end{array}$ & Kikoli & Zigua & Aloe & Red/green Aloe \\
\hline $\begin{array}{l}\text { Aloe (Unidentified) } \\
\text { (SA-53) }\end{array}$ & Ekighaka/Kighaka & Kurya & Aloe & Tall Aloe \\
\hline
\end{tabular}


Supplementary Data Table S2. Different uses of Aloe species in the study areas across Tanzania and their IUCN Red List status. The description of the IUCN Red List status: $\mathrm{CR}=$ Critically Endangered, $\mathrm{EN}=$ Endangered, $\mathrm{VU}=$ Vulnerable, $\mathrm{LC}=$ Least Concern and NE=Not Evaluated.

\begin{tabular}{|c|c|c|c|c|c|c|}
\hline Scientific name & Human ailment & Animal ailment & Cosmetic & $\begin{array}{l}\text { Local } \\
\text { brew }\end{array}$ & Others & $\begin{array}{l}\text { IUCN Red } \\
\text { List } \\
\text { Status }\end{array}$ \\
\hline A. ballyi & $\begin{array}{l}\text { Cough, Fever, Malaria, Stomachache, Ulcers, } \\
\text { Wounds }\end{array}$ & & & Alcohol & $\begin{array}{l}\text { Tiredness, To remove } \\
\text { jiggers from the body }\end{array}$ & EN \\
\hline A. bicomitum & $\begin{array}{l}\text { Amoeba, Bengu (Mpima in Fipa-yellow feces } \\
\text { accompanied with blood and swollen/tumor in } \\
\text { the stomach especially for children), Cough, } \\
\text { Fever, Flue, Headache, STD's, Stomachache, } \\
\text { Typhoid, Poison, Wounds }\end{array}$ & $\begin{array}{l}\text { Chicken } \\
\text { Newcastle } \\
\text { disease }\end{array}$ & & & & NE \\
\hline A. chabaudii & $\begin{array}{l}\text { Heart problems (Premature ventricular } \\
\text { contractions), Hernia, Stomachache, Typhoid }\end{array}$ & $\begin{array}{l}\text { Chicken } \\
\text { Newcastle } \\
\text { disease }\end{array}$ & & & Drunkenness & NE \\
\hline A. christianii & $\begin{array}{l}\text { Amoeba, Bengu, Cough, Earache, Ear pas, } \\
\text { Fever, Hernia, Malaria, Ringworms, } \\
\text { Stomachache, Swellings, Swollen legs, } \\
\text { Typhoid, Wounds }\end{array}$ & $\begin{array}{l}\text { Chicken } \\
\text { Newcastle } \\
\text { disease }\end{array}$ & & & $\begin{array}{l}\text { Sharp pain (Kichomi), } \\
\text { Sprains, Drunkenness, } \\
\text { Poison }\end{array}$ & NE \\
\hline A. deserti & $\begin{array}{l}\text { Earache, Fever, Kidney problems, Malaria, } \\
\text { Rashes, Spleen problems, Stomachache, } \\
\text { Wounds }\end{array}$ & $\begin{array}{l}\text { Cattle } \\
\text { pneumonia, } \\
\text { Cattle East } \\
\text { Coast Fever }\end{array}$ & & Alcohol & $\begin{array}{l}\text { Uvula (Kilimi), } \\
\text { Tiredness }\end{array}$ & VU \\
\hline A. dorotheae & Skin rushes, Diabetes, Malaria & $\begin{array}{l}\text { Chicken } \\
\text { Newcastle } \\
\text { disease }\end{array}$ & & & & CR \\
\hline A. duckerii & $\begin{array}{l}\text { Bengu, Burns, Colic, Cough, Pungu, Earache, } \\
\text { Ear pus, Fever, Headache, Hernia, Ovulation } \\
\text { Disorder (O.D), Ringworms, Stomachache, } \\
\text { Typhoid, Ulcers, Wounds }\end{array}$ & $\begin{array}{l}\text { Chicken } \\
\text { Newcastle } \\
\text { disease }\end{array}$ & $\begin{array}{l}\text { Malassezia } \\
\text { furfur } \\
\text { (Utangotango } \\
\text { wa ngozi) } \\
\end{array}$ & & $\begin{array}{l}\text { Against snake bite, } \\
\text { Poison, Sprains, Speed } \\
\text { up labor and delivery }\end{array}$ & NE \\
\hline A. flexilifolia & $\begin{array}{l}\text { Back pain, Colic, Diabetes, Ear pain, Fainted } \\
\text { person, Female infertility, Fungal infection, }\end{array}$ & $\begin{array}{l}\text { Chicken } \\
\text { Newcastle } \\
\text { disease }\end{array}$ & $\begin{array}{l}\text { Dandruff, } \\
\text { Cracks in feet }\end{array}$ & & $\begin{array}{l}\text { Lubricant for wooden } \\
\text { tires }\end{array}$ & CR \\
\hline
\end{tabular}




\begin{tabular}{|c|c|c|c|c|c|c|}
\hline & $\begin{array}{l}\text { Headache, Heart diseases, Hernia, HIV, } \\
\text { Malaria }\end{array}$ & & & & & \\
\hline A. lateritia & $\begin{array}{l}\text { Asthma, Abscess/ boil, Back pain, Bile, Colic, } \\
\text { Diabetes, Fungal infection, Gas in the } \\
\text { stomach, Heart diseases, Hernia, Blood } \\
\text { pressure, Female Infertility, Rushes, Ring } \\
\text { worms, Stomachache, Toothache, Wounds, } \\
\text { Typhoid }\end{array}$ & $\begin{array}{l}\text { Chicken } \\
\text { Newcastle } \\
\text { disease }\end{array}$ & Cracks in feet & & $\begin{array}{l}\text { Removing thorns, } \\
\text { Ornamental plant, To } \\
\text { remove stains in } \\
\text { clothes, Lubricant for } \\
\text { wooden tires }\end{array}$ & LC \\
\hline A. leptosiphon & $\begin{array}{l}\text { Back pain, Colic, Cough, Diabetes, Female } \\
\text { infertility, Headache, Heart diseases, Hernia, } \\
\text { Joint pain, Malaria, Blood pressure, Rashes, } \\
\text { Tooth ache, Tooth cavity, Typhoid, Ulcers, } \\
\text { Wounds. }\end{array}$ & $\begin{array}{l}\text { Chicken } \\
\text { Newcastle } \\
\text { disease, Cattle } \\
\text { East Coast } \\
\text { Fever }\end{array}$ & & & $\begin{array}{l}\text { Lubricant for wooden } \\
\text { tires, Pesticide }\end{array}$ & CR \\
\hline A. macrosiphon & $\begin{array}{l}\text { Abscess/ boil, Blood clotting after getting a } \\
\text { wound, Cleaning the stomach, Cough, Flue, } \\
\text { Fungus, Numbness (Ganzi), Heart diseases } \\
\text { (control heart beats), Bilharzia, Malaria, } \\
\text { Dysmenorrhea, Pimples, Stomachache, } \\
\text { Typhoid, Worms, Wounds, Yellow fiver }\end{array}$ & & & & & NE \\
\hline A. massawana & $\begin{array}{l}\text { Being numb, Hernia, Malaria, Prevent } \\
\text { bleeding, Ringworms, Round worms, } \\
\text { Toothache, Ulcers, Wounds }\end{array}$ & $\begin{array}{l}\text { Chicken } \\
\text { Newcastle } \\
\text { disease }\end{array}$ & & & & VU \\
\hline A. mzimbana & $\begin{array}{l}\text { Stomachache, Bengu, Fever, Hernia, } \\
\text { Pungu/Ndondo- (worms coming from the } \\
\text { anus), Typhoid, Wounds }\end{array}$ & $\begin{array}{l}\text { Chicken } \\
\text { Newcastle } \\
\text { disease }\end{array}$ & $\begin{array}{l}\text { Malassezia } \\
\text { furfur } \\
\text { (Utangotango } \\
\text { wa ngozi) }\end{array}$ & & $\begin{array}{l}\text { Speed up labor and } \\
\text { delivery }\end{array}$ & $\mathrm{NE}$ \\
\hline A. parvidens & Malaria, Wounds & & & & $\begin{array}{l}\text { Nairobi fly bite, } \\
\text { Tiredness }\end{array}$ & LC \\
\hline A. rabaiensis & $\begin{array}{l}\text { Bile, Earache, Fever, Kidney, Liver problems, } \\
\text { Malaria, Rashes, Spleen, Stomachache, } \\
\text { Ulcers, Pneumonia, Wounds }\end{array}$ & $\begin{array}{l}\text { Cattle East } \\
\text { Coast Fever, } \\
\text { Cattle } \\
\text { pneumonia }\end{array}$ & & Alcohol & Tiredness & LC \\
\hline A. secundiflora & $\begin{array}{l}\text { Bile, Cancer, Colic, Cough, Diabetes, } \\
\text { Earache, Eye ache, Fever, Gas in the } \\
\text { stomach, Gonorrhea (STDS), Hernia, Kidney, }\end{array}$ & $\begin{array}{l}\text { Chicken } \\
\text { Newcastle } \\
\text { disease, Cattle }\end{array}$ & & Alcohol & $\begin{array}{l}\text { To remove oil in meat } \\
\text { soup, Tiredness, To } \\
\text { remove Uvula (Kilimi) }\end{array}$ & LC \\
\hline
\end{tabular}




\begin{tabular}{|c|c|c|c|c|c|}
\hline & $\begin{array}{l}\text { Leg pain, Malaria, Pneumonia, Rashes, } \\
\text { Spleen, STD's, Stomachache, Toothache, } \\
\text { Wounds }\end{array}$ & $\begin{array}{l}\text { (gas in the } \\
\text { stomach), Cattle } \\
\text { East Coast } \\
\text { Fever }\end{array}$ & & & \\
\hline $\begin{array}{l}\text { A. volkensii ssp. } \\
\text { volkensii }\end{array}$ & Diabetes, Malaria, Stomachache, Wounds & $\begin{array}{l}\text { East Coast } \\
\text { Fever, Chicken } \\
\text { Newcastle } \\
\text { disease }\end{array}$ & & & LC \\
\hline $\begin{array}{l}\text { A. volkensii var. } \\
\text { multicalius }\end{array}$ & $\begin{array}{l}\text { Cough, Diabetes, Eye ache, Halitosis, Hernia, } \\
\text { Malaria, Pneumonia, Spleen, STD's, } \\
\text { Stomachache, Tooth ache, Wounds }\end{array}$ & $\begin{array}{l}\text { Cattle } \\
\text { constipation } \\
\text { (Kitasura- } \\
\text { Chaga), Cattle } \\
\text { East Coast } \\
\text { Fever, Chicken } \\
\text { Newcastle } \\
\text { disease }\end{array}$ & Alcohol & $\begin{array}{l}\text { To prevent bad eyes } \\
\text { and allows bananas to } \\
\text { flourish (local beleives), } \\
\text { Tiredness, To clean the } \\
\text { bowel, To remove oil in } \\
\text { meat soup }\end{array}$ & LC \\
\hline $\begin{array}{l}\text { Aloe (Unidentified- } \\
\text { SA 45) }\end{array}$ & Hernia, Malaria, Stomach ache, Wounds & $\begin{array}{l}\text { Chicken } \\
\text { Newcastle } \\
\text { disease }\end{array}$ & & & \\
\hline $\begin{array}{l}\text { Aloe (Unidentified- } \\
\text { SA 53) }\end{array}$ & Malaria & $\begin{array}{l}\text { Chicken } \\
\text { Newcastle } \\
\text { disease }\end{array}$ & & & \\
\hline
\end{tabular}

Footnotes to references: ${ }^{1}$ Dioli, Maurizio, T O M Mccoy, Maurizio Dioli, and Tom Mccoy. "Aloe elkerriana (Asphodelaceae), A new Ethiopian species from the type locality of Aloe jacksonii and Aloe Elkerriana (Asphodelaceae). Cactus and Succulent Society of America," 2007, 34-37; ${ }^{2}$ Wabuyele, E, Charlotte Sletten Bjora, Inger Nordal, and Leonard E Newton. "Distribution, Diversity and Conservation of the Genus Aloe in Kenya." Journal of East African Natural History 95, no. 2 (2006): 213-25. doi/10.2982/ 
Supplementary Data. Photographs for some of the Aloe species we found during our study and that had been utilized by the respondents $(n=236)$ in the study areas of Tanzania.

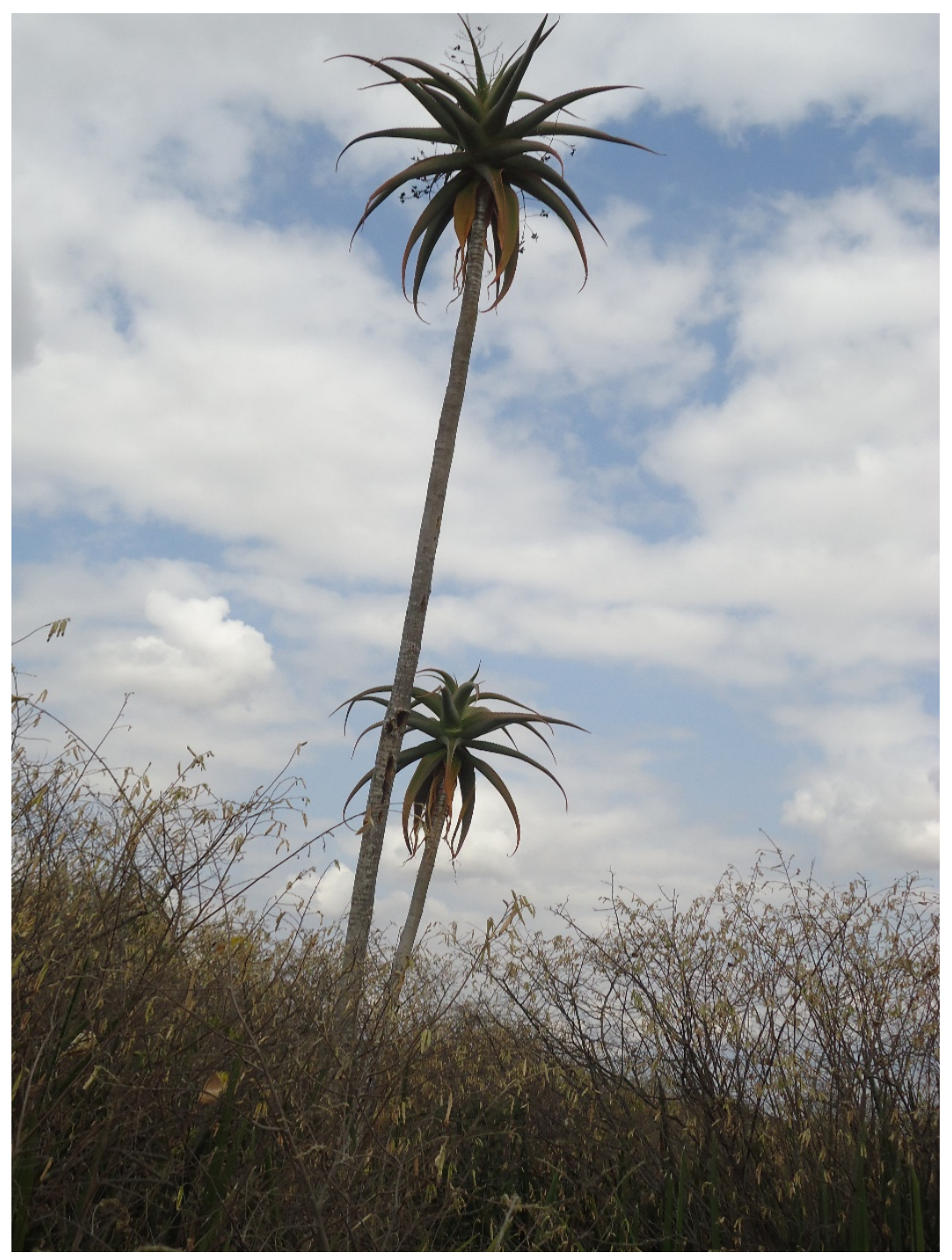

Supplementary Figure 1. Aloe ballyi collected from Lembeni, Kilimanjaro, in July 2018 (photo Siri Abihudi) 


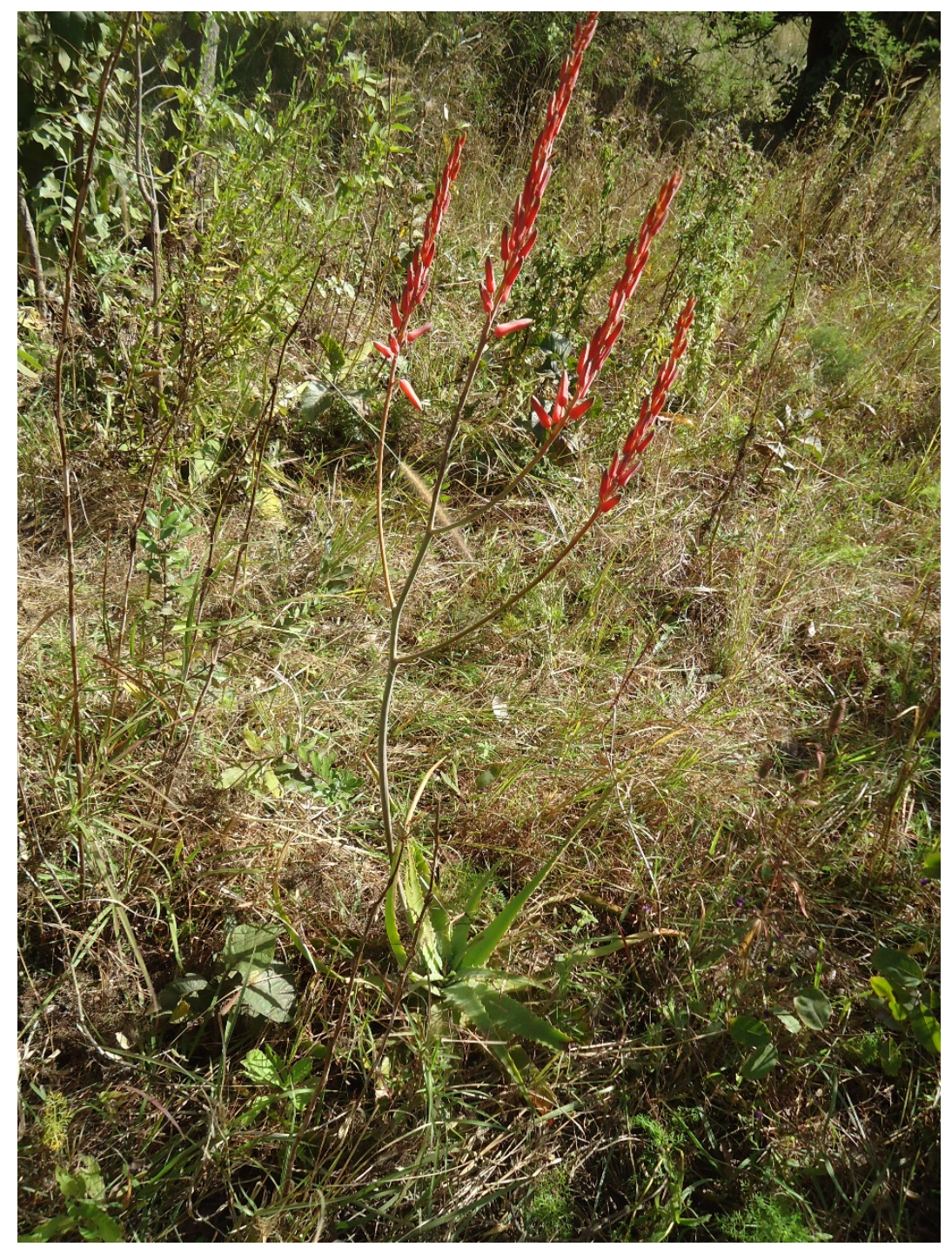

Supplementary Figure 2. Aloe christianii, collected from Tanganyika, Katavi, in May 2018 (photo Siri Abihudi) 


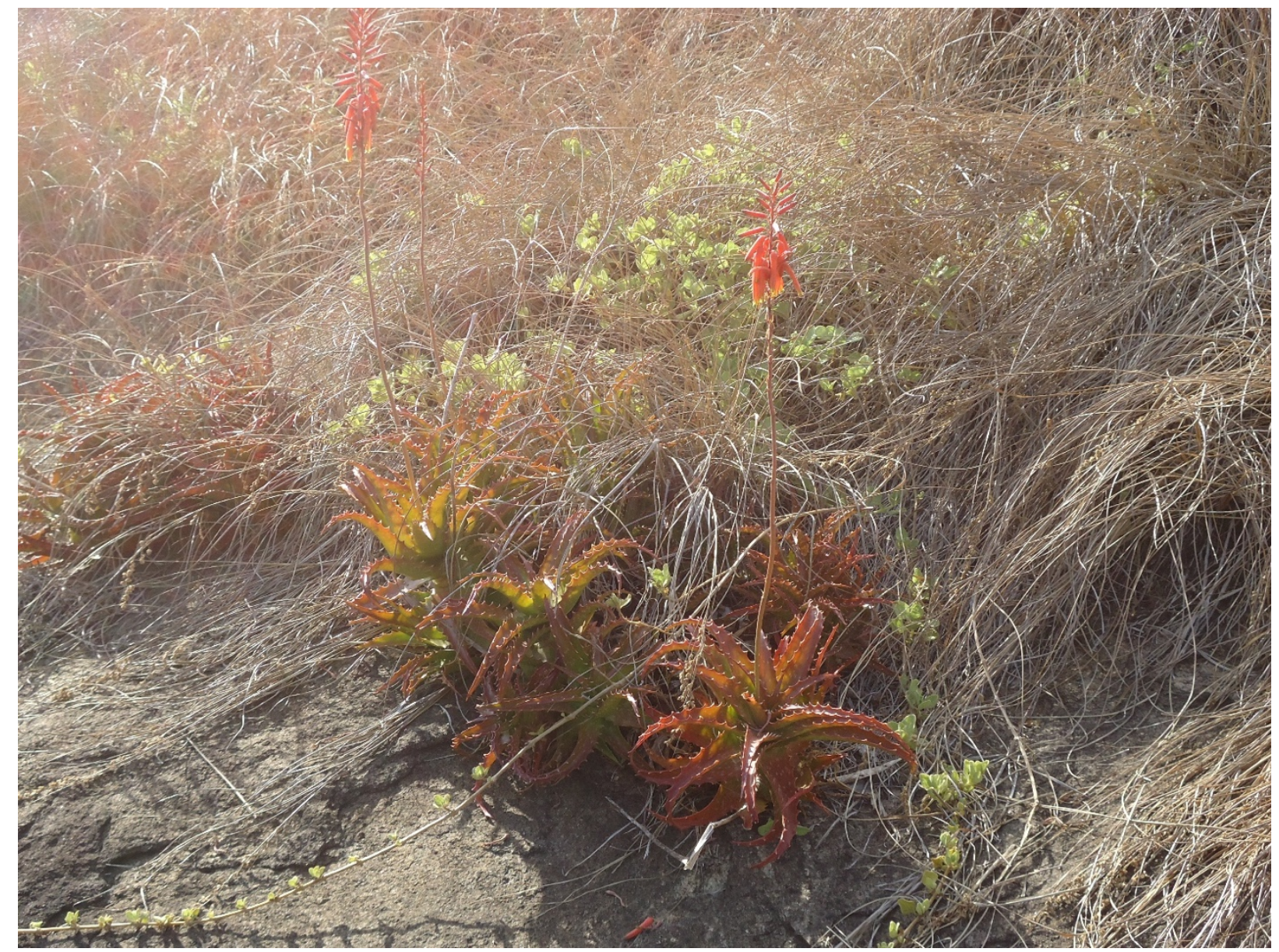

Supplementary Figure 3. Aloe dorotheae, collected from Handeni, Tanga, in April 2018 (photo Siri Abihudi) 


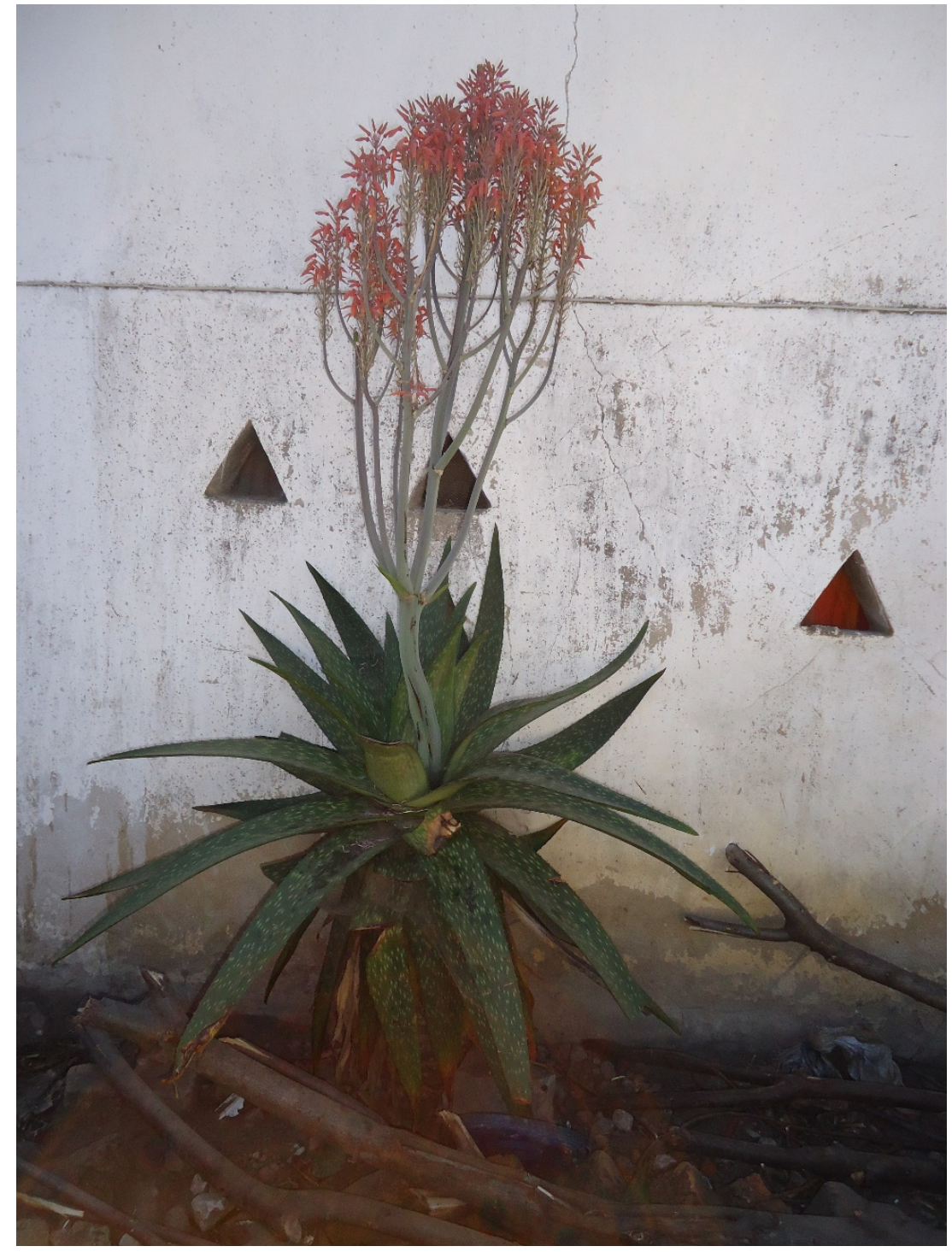

Supplementary Figure 4. Aloe duckerii, collected from, Kalambo district, Rukwa, in July 2018 (photo Siri Abihudi) 


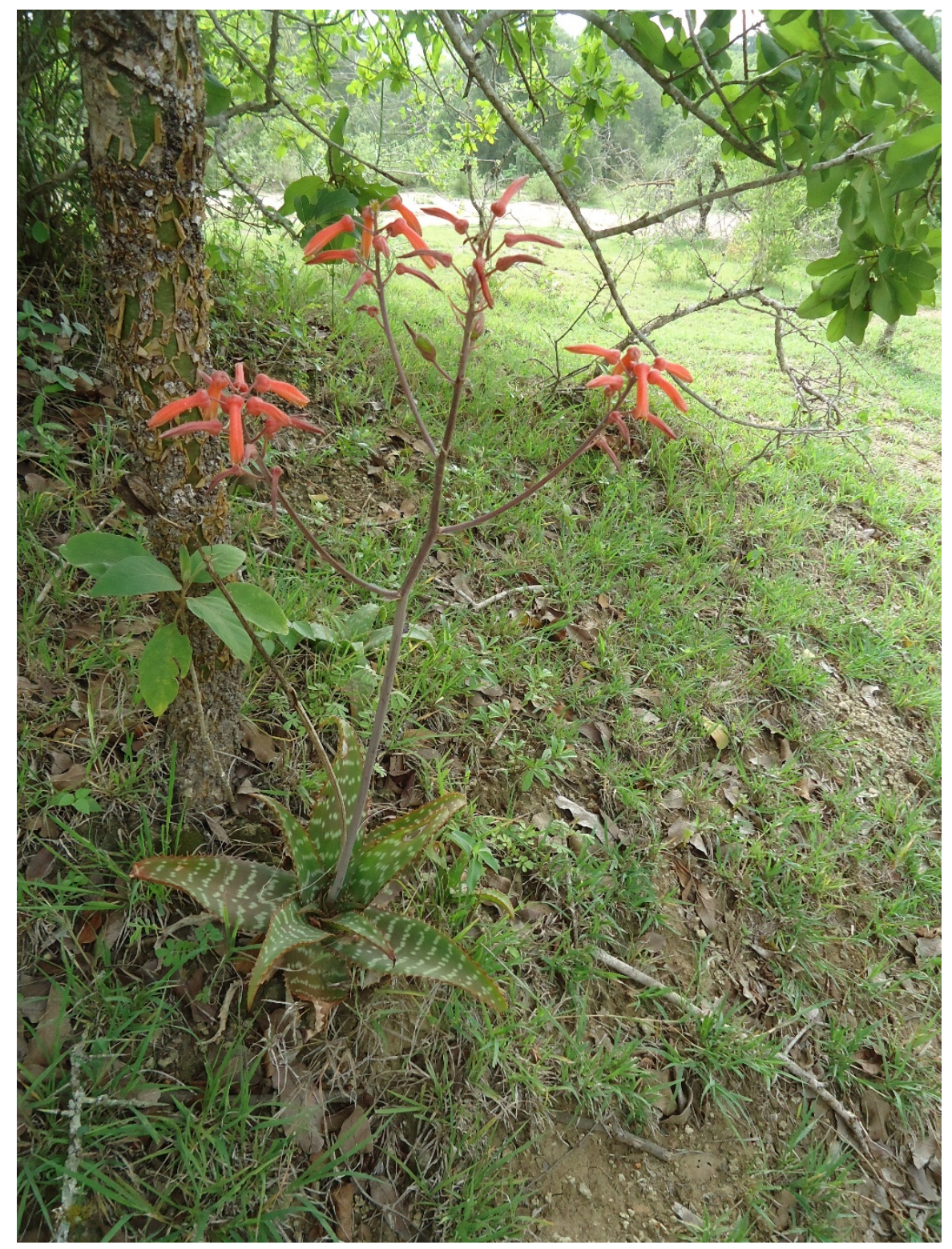

Supplementary Figure 5. Aloe lateritiria, collected from Handeni, Tanga, in April 2018 (photo Siri Abihudi) 


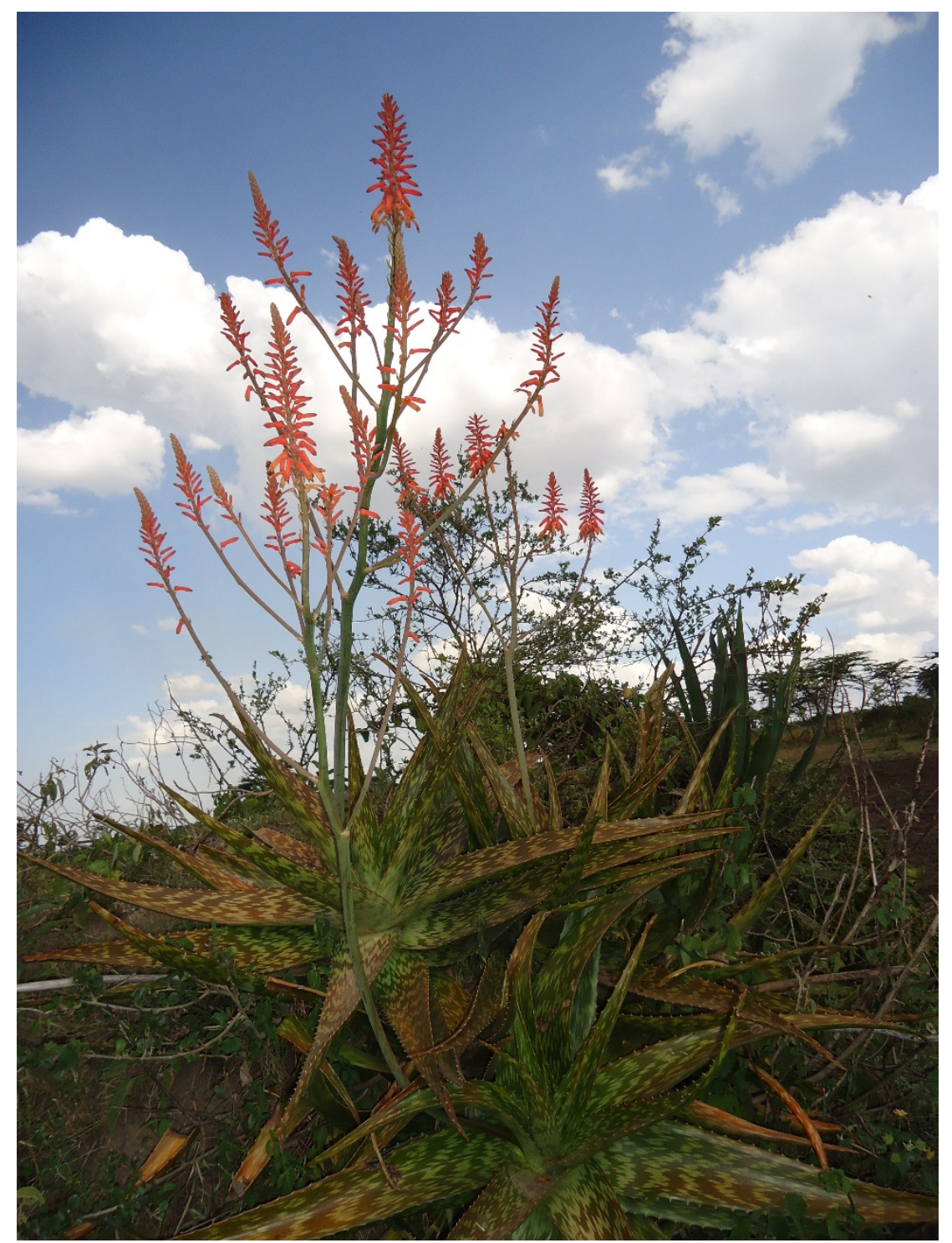

Supplementary Figure 6. Aloe macrosiphon, collected from Kisangura, Mara, in March 2018 (photo Siri Abihudi) 


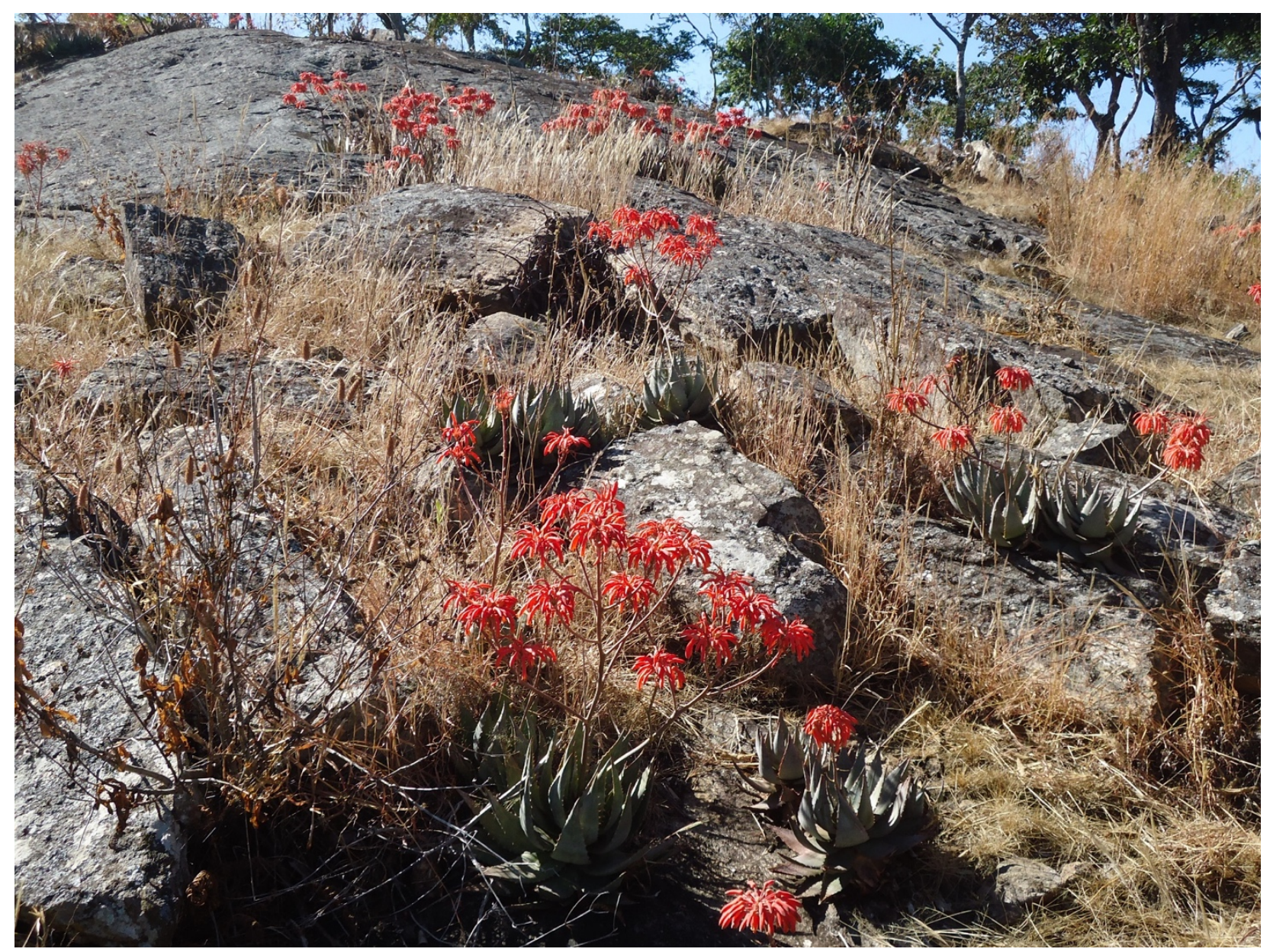

Supplementary Figure 7. Aloe mzimbana, collected from Mshani, Rukwa, in June 2018 (photo Siri Abihudi) 


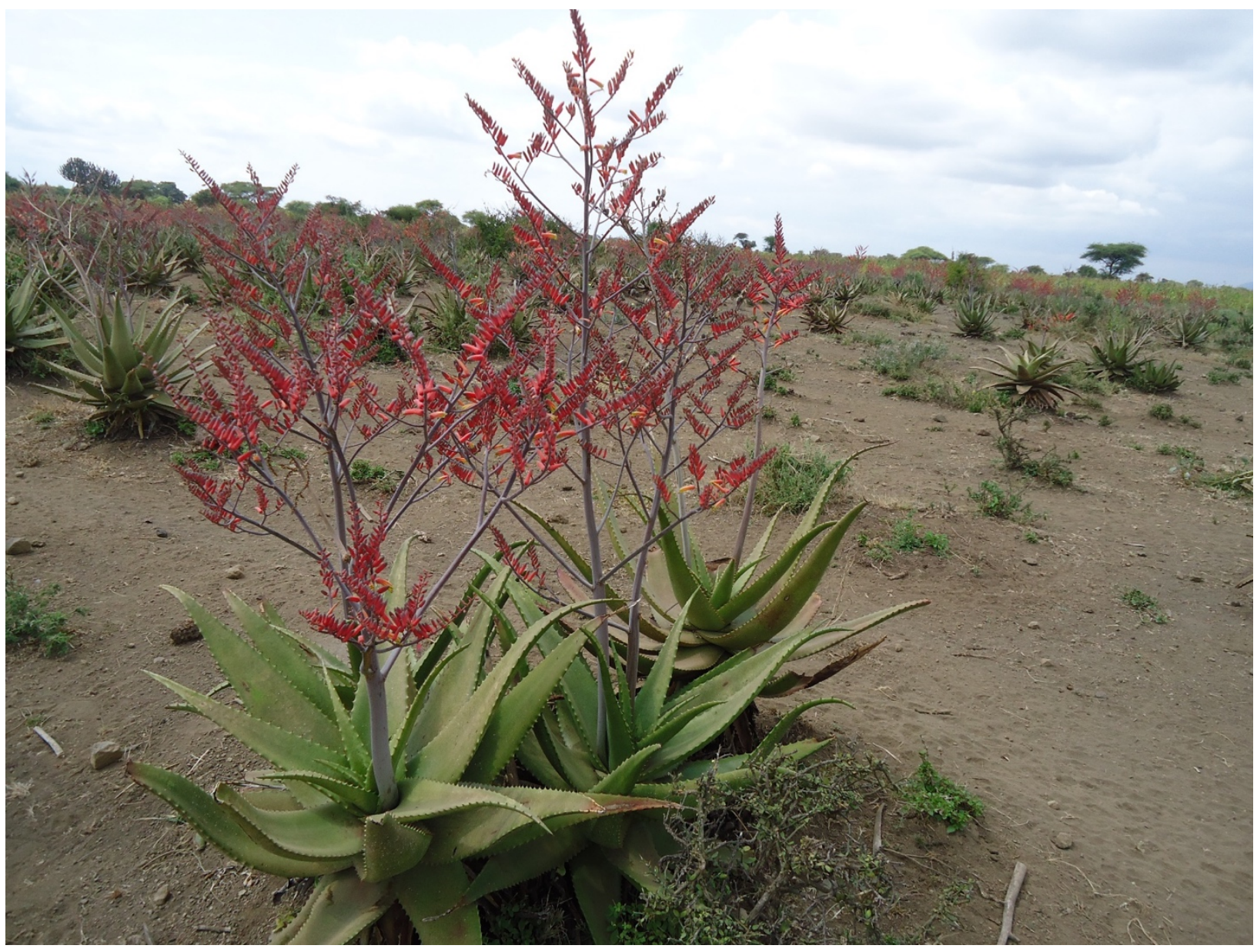

Supplementary Figure 8. Aloe secundiflora, collected from Chemka, Hai Kilimanjaro, in July 2018 (photo Siri Abihudi) 


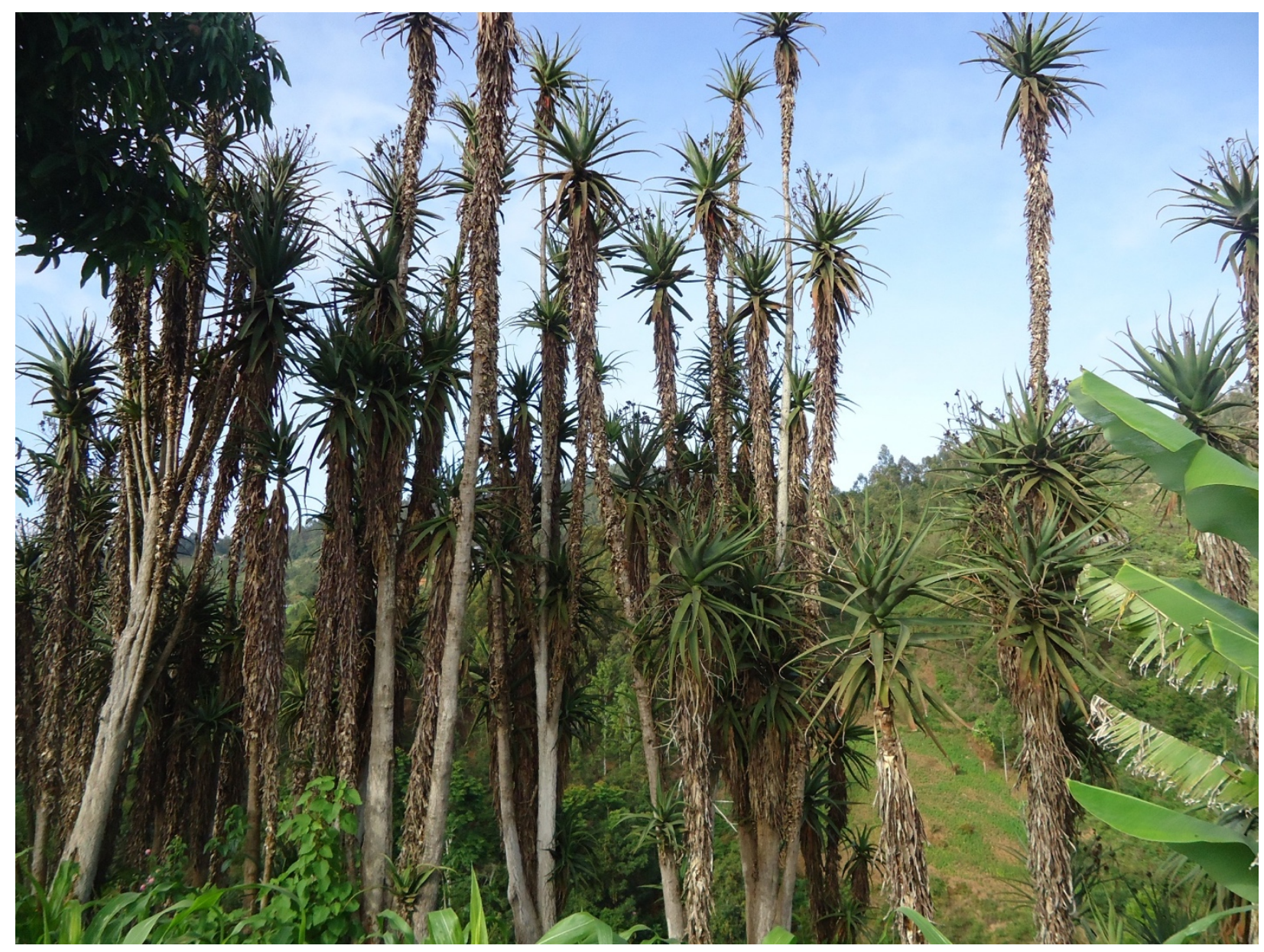

Supplementary Figure 9. Aloe volkensii subsp. multicalius, collected from Mlalo, Tanga, in July 2018 (photo Siri Abihudi) 